\title{
Evolutionary approaches for engineering industrially-relevant phenotypes in bacterial cell factories
}

\author{
Fernandez-Cabezon, Lorena; Cros, Antonin; Nikel, Pablo Ivan
}

Published in:

Biotechnology Journal

Link to article, DOI:

10.1002/biot.201800439

Publication date:

2019

Document Version

Peer reviewed version

Link back to DTU Orbit

Citation (APA):

Fernandez-Cabezon, L., Cros, A., \& Nikel, P. I. (2019). Evolutionary approaches for engineering industriallyrelevant phenotypes in bacterial cell factories. Biotechnology Journal, 14(9), [e1800439]. https://doi.org/10.1002/biot.201800439

\section{General rights}

Copyright and moral rights for the publications made accessible in the public portal are retained by the authors and/or other copyright owners and it is a condition of accessing publications that users recognise and abide by the legal requirements associated with these rights.

- Users may download and print one copy of any publication from the public portal for the purpose of private study or research.

- You may not further distribute the material or use it for any profit-making activity or commercial gain

- You may freely distribute the URL identifying the publication in the public portal 
Pablo Nikel ORCID iD: 0000-0002-9313-7481

Review Article

\title{
Evolutionary approaches for engineering industrially- relevant phenotypes in bacterial cell factories
}

\author{
by \\ Lorena Fernández-Cabezón, Antonin Cros, and Pablo I. Nikel* \\ The Novo Nordisk Foundation Center for Biosustainability, Technical University \\ of Denmark, 2800 Kgs Lyngby, Denmark \\ Running title: $\quad$ Engineering industrially-relevant phenotypes in bacteria \\ Keywords: Metabolic engineering - Industrially-relevant phenotypes · Adaptive \\ laboratory evolution · Synthetic Biology · Combinatorial engineering \\ Abbreviations: ALE, adaptive laboratory evolution; CRISPRi, CRISPR \\ interference; dCas9, inactive Cas9; dsDNA, double-stranded DNA; FACS, \\ fluorescence-activated cell sorting; GRAS, generally recognized as safe; MCF, \\ microbial cell factory; MMR, mismatch repair system; nCas9, Cas9 nickase; \\ sgRNA, single-guide RNA \\ * Correspondence to: Pablo I. Nikel (pabnik@biosustain.dtu.dk) \\ The Novo Nordisk Foundation Center for Biosustainability \\ Technical University of Denmark \\ 2800 Kgs Lyngby, Denmark \\ Tel: (+45 93) 511918 \\ Fax: (+45 45) 258000
}

This article has been accepted for publication and undergone full peer review but has not been through the copyediting, typesetting, pagination and proofreading process, which may lead to differences between this version and the Version of Record. Please cite this article as doi: 10.1002/biot.201800439.

This article is protected by copyright. All rights reserved. 


\begin{abstract}
Background: The bio-based production of added-value compounds (with applications as pharmaceuticals, biofuels, food ingredients, and building blocks) using bacterial platforms is a well-established industrial activity. The design and construction of microbial cell factories (MCFs) with robust and stable industriallyrelevant phenotypes, however, remains one of the biggest challenges of contemporary biotechnology. Purpose and scope: In this review, we discuss traditional and cutting-edge approaches for optimizing the performance of MCFs for industrial bioprocesses, rooted on the engineering principle of natural evolution (i.e. genetic variation and selection). Summary: We present state-of-the-art techniques to manipulate and increase genetic variation in bacterial populations and to construct combinatorial libraries of strains, both globally (i.e. genome-level) and locally (i.e. individual genes or pathways, and entire sections and gene clusters of the bacterial genome). Cutting-edge screening and selection technologies applied to isolate MCFs displaying enhanced phenotypes are likewise discussed. Conclusion: We close the review article by presenting future trends in the design and construction of a new generation of MCFs that will contribute to the long-soughtafter transformation from a petrochemical industry to a veritable sustainable biobased industry.
\end{abstract}

\title{
Graphical Abstract
}

The development of efficient bacterial cell factories requires the optimization of phenotypic features at different levels of regulation. This review summarizes the major approaches that can be used for this purpose, including classical programs of mutagenesis and selection and cutting-edge technologies for targeted genome edition.

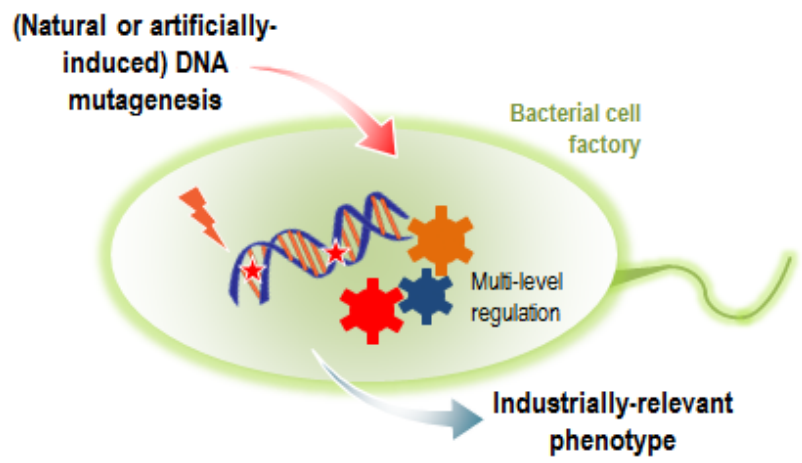

This article is protected by copyright. All rights reserved. 


\section{Introduction}

The use of microorganisms as platforms for the production of added-value compounds has a long tradition ${ }^{[1]}$ and, over the years, has become a wellestablished industrial activity. ${ }^{[2]}$ Many of these activities are rooted on fascinating scientific discoveries, e.g. that yeast is the biocatalyst responsible for the fermentation of beer and wine-which, over the years, lead to the establishment of yeast as a platform for bioproduction. ${ }^{[3]}$ Bio-based compounds are increasingly being used as pharmaceuticals, food ingredients, biofuels, and chemical precursors (building blocks), among other relevant applications. ${ }^{[4]}$ The development of sustainable lifestyles, which should meet current human needs without compromising the Earth's resources or its future, requires novel, efficient biomanufacturing methods for the synthesis of such products. ${ }^{[5]}$ Along the same line of reasoning, streamlined workflows for the design, construction, and testing of microbial cell factories (MCFs) are key to support the long-sought-after transformation from a petrochemical industry to a more sustainable bio-based industry.

An ideal MCF is expected to display (i) fast growth in low-cost, defined culture media up to high cell densities, (ii) absence of determinants of pathogenicity (and, if possible, generally recognized as safe-GRAS-status), (iii) extended genetic stability, (iv) high yield (gproduct $\mathrm{g}_{\text {substrate }}{ }^{-1}$ ), productivity (g groduct $^{-1} \mathrm{~h}^{-1}$ ) and product titer (gproduct $\mathrm{L}^{-1}$ ), (v) efficient product secretion, and (vi) limited formation of byproducts. ${ }^{[6]}$ In addition, MCFs should grow and produce the compound of interest under culture conditions that are optimal for the overall industrial process, including ease of culture media preparation and simple downstream steps. ${ }^{[7]}$ This last aspect is particularly challenging, since cell viability can be compromised by factors such as adverse industrial conditions, presence of growth inhibitors in raw materials, or accumulation of toxic compounds during the fermentation. Thus, the

This article is protected by copyright. All rights reserved. 
design and construction of MCFs with robust phenotypes continues to be one of the grand challenges of industrial biotechnology ${ }^{[8]}$ Historically, this overarching task has been addressed through different methodologies that include (i) classical mutagenesis approaches, (ii) adaptive laboratory evolution (ALE), (iii) rational pathway engineering, and (iv) combinatorial approaches. We start by summarizing the main aspects of each of these approaches to set the stage for the discussion of novel, emerging methodologies for the optimization of bacterial cell factories.

In classical approaches for strain improvement, microorganisms capable of producing the compound(s) of interest are isolated and subjected to successive rounds of random DNA mutagenesis followed by screening of enhanced properties. This methodology is epitomized in the isolation of Penicillium chrysogenum NRRL1951 (some six decades ago) followed by mutagenesis and screening programs that led to the development of industrial strains with a $>1,000$-fold increase in penicillin productivity. ${ }^{[9]}$ Although useful and simple, these programs are usually laborious and time-consuming. The emergence of Metabolic Engineering as a discipline in the 1990s—with the main purpose of improving cellular activities through targeted manipulation of enzymatic, transport, and regulatory functions via recombinant DNA technologies-resulted in the implementation of rational approaches for the construction of MCFs. ${ }^{[10]}$ Classical MCF programs gave way to the engineering of new enzymatic activities and biosynthetic routes, implanted in well-established hosts, ${ }^{[11]}$ to produce both natural and non-natural products and to expand Nature's chemical repertoire. ${ }^{[12]}$ In time, the development of innovative experimental and computational tools enabled the emergence of Systems Metabolic Engineering, a systematic and high-throughput discipline that integrates traditional Metabolic Engineering approaches with other fields such as Systems Biology and Synthetic Biology. ${ }^{[13]}$ Thus, strategies for MCFs design are now taken onto a global scale, simultaneously considering the upstream (i.e. strain development), midstream (i.e. fermentation), and downstream (i.e. separation and purification) stages of the bioprocess. Several examples in the

This article is protected by copyright. All rights reserved. 
primary literature have demonstrated the efficacy of such global approaches in improving phenotypes of industrial interest. The cost-efficient production of the amino acids L-lysine and L-arginine by Corynebacterium glutamicum, the bulk chemical 1,4-butanediol by Escherichia coli, and the antimalarial drug precursor artemisinic acid by Saccharomyces cerevisiae, are just a few instances of bioprocesses that have found their way from the laboratory into actual industrial setups. ${ }^{[14]}$

Although Systems Metabolic Engineering opened new avenues for MCF design and construction, these endeavors still require a substantial quantitative knowledge of the microbial host and the ability to reliably predict responses to multiple genetic or environmental manipulations (i.e. tracing genotype-to-phenotype relationships). These issues remain to be considerable challenges, especially when using alternative microbial hosts other than E. coli or S. cerevisiae. Low product yields are often tied to a decrease in cell viability and genetic instability during scale-up and under industrial production conditions ${ }^{[15]}$ _ even after comprehensive optimization of biosynthetic pathways. In addition, establishing a genetic toolbox for the engineering of non-model microbes is still a daunting task. ${ }^{[16]}$ All of these aspects slow down the development of economically-viable MCFs and bioprocesses_and, indeed, a relatively small number of these rationallyengineered strains can be scaled-up in an industrial context. ${ }^{[17]}$ Therefore, random whole-genome engineering approaches, e.g. via ALE, ${ }^{[18]}$ have taken the optimization of industrially-relevant phenotypes into a wider space as compared to the use of rational approaches.

ALE, also known as evolutionary engineering, follows natural evolution's 'engineering principles' of genetic variation and selection. ${ }^{[19]}$ Individual cells in a microbial population randomly accumulate mutations, either as consequence of natural DNA replication errors or via externally-induced mutagenesis mechanisms. ${ }^{[20]}$ Some (beneficial) mutations encode phenotypic changes that allow mutants to grow and divide faster than other cells under specific culture conditions,

This article is protected by copyright. All rights reserved. 
eventually taking progressive control of the entire population. ${ }^{[21]}$ As the selective pressure is increased, other beneficial mutations can be selected for until the desired objective is achieved via gradual increases in fitness. ${ }^{[22]}$ ALE experiments have been applied successfully to improve a number of wild-type and engineered microorganisms and bioprocesses. ${ }^{[23]}$ ALE possesses clear benefits over rational engineering methods, including (i) broad applicability to different microbial hosts, (ii) ease of practical implementation, (iii) potential discovery of new, non-intuitive regulatory mechanisms, and, most importantly, (iv) ALE facilitates at least some improvement of many industrially-relevant phenotypes. The power of ALE notwithstanding, the construction of combinatorial libraries of strains also attracts increasing attention. ${ }^{[24]}$ These methodologies, if coupled with adequate screening and selection assays, can be applied to fine-tune the expression of metabolic pathway genes (i.e. via combinatorial pathway engineering) and optimize complex phenotypes (whole-genome combinatorial techniques; e.g. via whole-genome mutant libraries, genome shuffling, ribosome engineering). One way or the other, highly-efficient MCFs can only be obtained via increasing genetic variation and imposing restrictive selection schemes towards the phenotype of interest. Some examples of industrially-relevant phenotypes that have been engineered by adopting evolutionary approaches are listed in Table $\mathbf{1 .}$

From the examples discussed above, it becomes clear that there is room for the development of novel approaches aimed at MCF optimization. In this review, we discuss methodologies for the improvement of bacterial cell factories for industrial bioprocesses via the general principle of evolution based on genetic variation and selection (Fig. 1). Interestingly, these approaches mirror historical human activities for the domestication of crops and animals. ${ }^{[25]}$ Firstly, we present relevant techniques currently available to increase genetic variation in the bacterial population, both globally (genome-wide) and locally (individual genes or genome sections). Secondly, we discuss different screening and selection technologies that can be applied to exploit genetic variation with the ultimate goal of isolating

This article is protected by copyright. All rights reserved. 
mutant strains with improved phenotypes. Based on these principles, we close the article by presenting future trends in the design and construction of the next generation of MCFs that will mediate the transition towards a more sustainable biobased industry.

\section{Strategies to increase phenotypic variation in bacterial populations}

A number of techniques have been implemented in recent years to increase genetic variation in bacterial populations, leading the phenotypic diversification (Table 2). Several criteria must be considered when selecting an appropriate technique to be used, e.g. characteristics of the bacterial host, the type of phenotype to be improved, and the expected application/use of the resulting strain. For instance, the improvement of complex phenotypes often requires the implementation of wholegenome approaches, since the exact mechanisms (i.e. metabolic, regulatory, or both) underlying the phenotype of interest are usually unknown. Targeted DNA mutagenesis approaches, however, can be implemented to generate genetic variation (i.e. DNA mutations) in specific genes or genomic regions when some information about the genotype-to-phenotype relationship is available (e.g. finetuning the expression level of genes within heterologous biosynthetic pathways or discovering new protein variants with improved properties). The most relevant whole-genome and targeted mutagenesis approaches described to date are discussed in the next two sections.

\subsection{Whole-genome approaches to increase genetic variation}

Whole-genome random mutagenesis: external mutagenic agents and use of mutator strains

Mutations in DNA are one of the most important sources of genetic variation and,

therefore, are fundamental to natural evolution. ${ }^{[26]}$ Small and transient increases in mutation rate(s) have been shown to significantly improve the probability of

This article is protected by copyright. All rights reserved. 
generating beneficial, fitness-increasing mutations to accelerate the improvement of MCFs performance, since intrinsic mutation rates are usually low for most organisms (typically in the order of $10^{-9}-10^{-10}$ events per base pair per generation). ${ }^{[27]}$ The process of evolution-through-mutagenesis is a natural occurrence in environmental bacteria, ${ }^{[28]}$ which is especially relevant for the emergence of novel catabolic routes for xenobiotic biodegradation. ${ }^{[29]}$ DNA mutagenesis can be externally triggered by chemical or physical mutagens or internally mediated by (conditional) mutator phenotypes (Table 2 and Fig. 2A).

Chemical and/or physical mutagenesis has traditionally been used for the optimization of industrial strains, due to the simplicity of its technical implementation and its applicability to virtually any microorganism. ${ }^{[30]}$ The design of a successful mutagenesis protocol, however, is not a trivial task. The selection of an optimal dose of mutagen(s), which would generate sufficient genetic variation without increasing too much the frequency of (unavoidable) detrimental mutations in the genome, is a particularly critical step. In addition, since most mutagens preferentially introduce certain types of mutations in the target DNA-e.g. alkylating agents, such as ethyl methanesulfonate and 1-nitro-1(nitrosomethyl)guanidine, induce $\mathrm{GC} \rightarrow \mathrm{AT}$ transitions-mutagens should be switched periodically along the mutagenesis program. Commonly-used chemical mutagens encompass base analogs, intercalating agents, and base modifiers; while physical mutagens include ultraviolet light, electromagnetic radiation (e.g. $\gamma$ and $X$ radiation), and high-energy particle radiation (e.g. $\alpha$ and $\beta$ particles). ${ }^{[30]}$ An alternative mutagenic method, based on radio-frequency atmospheric-pressure glow discharge plasma and termed atmospheric and room temperature mutagenesis, offers some advantages over traditional mutagens (e.g. larger variation of the potential mutants and safer operating conditions than those afforded by the use of dangerous radiation sources), yet it requires specialized equipment that can limit its widespread use. ${ }^{[31]}$

This article is protected by copyright. All rights reserved. 
Genome-wide random mutagenesis can also be genetically induced by using conditional mutator phenotypes. Mutator strains are bacteria displaying high mutation rates, since they have mutations in one or several genes encoding DNA repair or error-avoidance systems. ${ }^{[32]}$ For example, specific mutations in components of the DNA mismatch repair system (MMR; e.g. mutL, mutH, and mutS) or in proofreading DNA polymerases (e.g. dnaQ), as well as the overexpression of certain dominant mutator alleles of the same genes, have been shown to result in strong mutator phenotypes. Mutator strains have been investigated for decades, and they appear to occur naturally in bacterial populations that are propagated for prolonged periods under identical conditions ${ }^{[33]}$ —also in pathogenic bacteria. ${ }^{[34]}$ Mutator strains were initially used to introduce random mutations in extrachromosomal DNA (e.g. plasmids); ${ }^{[35]}$ however, mutator phenotypes have subsequently been applied to the phenotypic optimization of several bacterial species (e.g. E. coli, Lactobacillus casei, Synechococcus sp., Bacillus subtilis, and Clostridium acetobutylicum). ${ }^{[36]}$ Since mutation rates must be controlled to avoid extensive accumulation of deleterious mutations and prevent genomic instability, the overexpression of dominant mutator alleles is generally driven from tightly-regulated expression systems that can be subsequently removed from isolated cells displaying the phenotype of interest. ${ }^{[37]}$ Most mutator allelles preferentially introduce certain types of mutations because they act on different mechanisms of DNA replication fidelity. ${ }^{[32]}$ For example, transition and frameshift mutations or tranversions can be randomly created in bacterial cells by interfering with the MMR system or the proofreading activity encoded by the $d n a Q$ gene, respectively. A broader mutational spectrum can be achieved by simultaneously interfering with several DNA fidelity mechanisms, e.g., by overexpressing multiple mutator alleles. ${ }^{[38]}$ Due to the difficulty of achieving an optimal mutation rate in each experiment, mutagenesis is sometimes coupled with selection and, at the same time, modulation of mutation rates during the run. For this purpose, Luan et al. ${ }^{[39]}$ constructed a library of $E$. coli mutants that overexpress $d n a Q$ variants displaying several mutation rates and mutational spectra. This strategy was successfully

This article is protected by copyright. All rights reserved. 
applied to improve the tolerance of $E$. coli strains towards $n$-butanol, acetate, and thermal challenges. ${ }^{[40]}$ Alternatively, genetic circuits that enable dynamic changes in the mutation rate according to a particular phenotype can be used (e.g. based on biosensors). Chou and Keasling, ${ }^{[41]}$ for instance, developed an adaptive control system (evolution of feedback-regulated phenotypes) that enables the regulation of mutation rates by expressing a dominant mutator allele in a fashion inversely proportional to the concentration of the target metabolite. This dynamic system has been used to increase the production of L-tyrosine and isoprenoids in engineered $E$. coli strains. Similarly, Pham et al. ${ }^{[42]}$ designed a riboswitch-based $\mathrm{pH}$-sensing genetic device to control gene expression according to the environmental $\mathrm{pH}$, and used this device for evolutionary engineering of $E$. coli for improved tolerance to a broad spectrum of organic acids.

\section{Genome shuffling}

Genome shuffling was first implemented in 2002 in separate attempts to improve the production of the antibiotic tylosin by Streptomyces fradiae and to increase acid tolerance of Lactobacillus strains. ${ }^{[43]}$ This technology, based on the construction of libraries of mutant strains through the recursive fusion of protoplasts (i.e. forcing recombination events between genomes), enables the introduction of multiple genetic changes simultaneously without any a priori knowledge of genome sequences or genetic networks (Table 2 and Fig. 2B). As such, genome shuffling is especially useful for the rapid improvement of complex phenotypes in non-wellcharacterized bacterial hosts. In addition, and from a regulation perspective, the resulting (i.e. shuffled) strains are not considered to be genetically-modified microorganisms. $^{[44]}$

Genome shuffling requires a parental population displaying good genetic variation and sufficient diversity in the traits relevant for the industrially-relevant phenotype of interest. This technique is typically initiated by subjecting the parental population to repeated cycles of random mutagenesis. Next, several parental strains

This article is protected by copyright. All rights reserved. 
are selected, protoplasts are prepared, and then fused in several shuffling rounds. Finally, shuffled strains are screened, and the most promising candidates can be subjected to new genome shuffling cycles if needed. The phenotypic improvements achieved after only a few shuffling rounds have been demonstrated to be comparable to those resulting from multi-year, classical strain improvement. ${ }^{[43 a]}$ In addition, genome shuffling is a quite cost-effective and easy-to-handle technology-although its application is largely limited to Gram-positive bacteria. A small number of examples of genome shuffling in Gram-negative species are available (e.g. E. coli, Pseudomonas parafulva, and Sphingobium chlorophenolicum), probably due to the fact that protoplast fusion is less efficient in these bacteria. ${ }^{[45]}$ However, mechanisms for horizontal gene transfer (e.g. conjugation, transduction, and transformation)—many of which have higher efficiency in Gram-negative bacteria—might be exploited to foster recombination in these species. ${ }^{[44 c]}$

\section{Construction of whole-genome mutant libraries}

Gene function(s) can be investigated in a dynamic system through systematic gene knock-down, knock-out, or overexpression. On the basis of this premise, wholegenome combinatorial libraries of mutants have been constructed and applied to identify relevant genetic targets for strain improvement in numerous bacterial species (Table 2). The main advantage of this approach is that the resulting phenotype (if identified) can be easily linked back to a single or a small set of genetic perturbations. In addition, genes encoding regulatory proteins or proteins with unknown functions contributing to the relevant phenotype (which could not be predicted by rational approaches), can be identified by implementing these techniques. Once the combinatorial strain libraries have been constructed, they can be used in multiple screenings of individual mutants or in competition fitness assays with several pools of mutants. ${ }^{[46]}$

This article is protected by copyright. All rights reserved. 
Libraries of random knock-out mutants have traditionally been constructed by transposon insertion mutagenesis, involving the random integration of an antibiotic resistance gene into the target genome mediated by the activity of a transposase (Fig. 2C). This technique has several advantages, e.g. technical simplicity and broad applicability to multiple microbial species; however, an unbiased integration of transposons or possible pleiotropic effects may hinder the identification of relevant targets to unravel genotype-to-phenotype relationships. ${ }^{[47]}$ Some of these limitations can be overcome by constructing in-frame, single-gene knock-out mutants, such as the KEIO collection derived from wild-type E. coli K-12 strain BW25113. ${ }^{[48]}$ The creation of strain libraries has been possible thanks to the development of efficient techniques for bacterial genome engineering (e.g. recombineering). ${ }^{[49]}$ Alternatively, knock-down libraries can be obtained using clustered regularly interspaced short palindromic repeats (CRISPR) interference (CRISPRi), which allows for transcriptional downregulation of virtually any gene in bacterial genomes. ${ }^{[50]}$ CRISPRi targets can be easily programmed in silico by substituting the first 20 nucleotides of the single-guide RNA (sgRNA) sequence to match the non-template strand of the target gene. As such, the design and construction of CRISPRi libraries (i.e. genome-wide collections of sgRNAs) that target specific sets of genes or the entire genome is now a straightforward task. Since CRISPRi knock-downs can be induced, titrated, and tuned, all genesincluding essential ones, which cannot be accessed via knock-outs—can be systematically targeted. Despite these clear technical advantages, the construction of CRISPRi libraries has been used in only a few bacterial species thus far (e.g. E. coli, B. subtilis, and Streptococcus pneumoniae), ${ }^{[51]}$ due to the fact that CRISPRi components have been transferred using species-specific or narrow-host-range strategies and also because functional elements should be optimized in a speciesdependent fashion. To overcome this barrier, Peters et al. $^{[52]}$ have recently developed mobile-CRISPR - a suite of modular and transferable CRISPRi components that can be stably integrated into the genomes of diverse bacterial species.

This article is protected by copyright. All rights reserved. 
Gene overexpression libraries have been traditionally designed by using genomic expression variants that help identifying suitable genetic targets, i.e. individual genes or operons found in the cloned genomic fragments that improve the desired phenotype(s) (Fig. 2D). Technological advances and the availability of genome sequence data enabled the creation of full-length open reading frame (ORF) libraries, such as the ORFeome collection of E. coli K-12 (ASKA collection), ${ }^{[53]}$ which has simplified the investigation of genotype-to-phenotype relationships and the optimization of gene expression. ORF libraries are constructed by PCR amplification or chemical synthesis of each individual ORF followed by systematic cloning of the fragments in a suitable expression vector. Overexpression libraries can now be constructed using genomic DNA or synthetic DNA based on the genomic information of the microbial host or other organisms with traits of interest-as well as with metagenomic DNA samples. For example, the heterologous expression of genomic libraries from Piriformospora indica and Marinobacter aquaeolei in E. coli allowed for the identification of genes conferring tolerance to salt and terpenes, respectively. ${ }^{[54]}$

Combinatorial libraries have been successfully adopted to improve growth-related phenotypes (e.g. stress tolerance and substrate utilization), and they have been remarkably convenient to improve industrially-relevant phenotypes (e.g. lycopene production in engineered $E$. coli ${ }^{[55]}$ and acid tolerance in Clostridium acetobutylicum $^{[56]}$ ). However, these approaches only allow for the identification of individual gene contributions to the phenotype of interest, so they often need to be combined with each other or with other methodologies to achieve phenotypic improvements. For example, complex gene interactions can be investigated by using co-expressing genomic libraries, created by combining two compatible overexpression libraries. ${ }^{[57]}$ Pooled competition fitness assays can also be coupled to next generation sequencing technologies, which allows for monitoring the enrichment of certain mutants in the microbial population (e.g. transposon insertion sequencing, SCALE). ${ }^{[58]}$ Emerging genome editing technologies, combined with

This article is protected by copyright. All rights reserved. 
barcoding technology, can be likewise implemented for the easy, time-efficient construction of whole-genome combinatorial libraries of mutants. ${ }^{[59]}$ Yet, the expression of individual or multiple genes can be also manipulated at a global level by engineering transcriptional regulation as disclosed in the next section.

\section{Engineering transcriptional regulatory proteins}

The direct or indirect manipulation of transcriptional regulatory networks has been exploited for the construction of efficient MCFs. ${ }^{[60]}$ The engineering of transcriptional regulatory proteins (TRPs) enables the alteration of the expression of hundreds of genes at the same time, eliciting the appearance of complex traits (Table 2). In this approach, TRPs capable of reprogramming cell metabolism and regulation are firstly identified to improve complex phenotypes. TRPs can be native, exogenous, or synthetic (i.e. artificial) proteins, and they can function locally or globally, depending on the number of genes and the range of cellular functions to be targeted. ${ }^{[61]}$ After the selection of one or several TRP(s), the workflow involves the creation of a library of variants of the selected proteins, the expression of the resulting library in the host, and the subsequent selection of the desired phenotype-iterating the entire process as many times as necessary (Fig. 2E). The identification and characterization of TRPs, e.g. by randomized knock-out and overexpression libraries, is an essential aspect for the successful application of this methodology.

One of the most widely used approaches in this sense has been the modification of $\sigma$ factors (global transcription machinery engineering). ${ }^{[62]}$ These TRPs bind to the promoter regions with varying degrees of affinity and help recruiting the holoenzyme RNA polymerase to initiate transcription. Therefore, small variations in the activity, specificity, or affinity of $\sigma$ factors have the potential to greatly affect the subset of genes that are bound by RNA polymerase. The $\sigma$ factor $\sigma^{70}$ (RpoD) and, to a lesser extent, $\sigma^{38}$ (RpoS), have been targets for global transcription machinery engineering in several bacteria (e.g. E. coli, Lactobacillus plantarum,

This article is protected by copyright. All rights reserved. 
Klebsiella pneumoniae, and Zymomonas mobilis). ${ }^{[63]}$ Other endogenous global regulators, e.g. H-NS (histone-like nucleoid structuring factor), the cAMP receptor protein (CRP), and the RNA polymerase itself (RpoA), have been engineered in $E$. coli to improve several complex phenotypes. ${ }^{[64]}$ Analogously, the pleiotropic TRPs CodY and CcpA have been targeted to increase recombinant protein production in B. subtilis. ${ }^{[65]}$ In addition to native TRPs, the exogenous global regulator IrrE of the radiation-resistant bacterium Deinococcus radiodurans has the potential to act as a global regulator in E. coli, and to enhance its resistance against ethanol, butanol, and acetate-especially after engineering of the TRP. ${ }^{[66]}$ Similarly, the $\sigma$ factors $\sigma^{\mathrm{HrdB}}$ of Actinoplanes missouriensis, Micromonospora aurantiaca, and Salinispora arenicola, have been selected for cycles of random mutagenesis/DNA shuffling and introduced into Actinoplanes teichomyceticus to improve the biosynthesis of the antibiotic teicoplanin. ${ }^{[67]}$ Libraries of artificial TRPs can also be designed to reprogram the entire bacterial transcriptome. For example, synthetic TRPs based on zinc finger motifs have been used to optimize complex phenotypes in E. coli (e.g. resistance to heat shock, osmotic pressure and cold shock $\left.{ }^{[68]}\right)$. In these examples, libraries of mutant TRPs were constructed by randomly assembling 3-4 zinc-finger motifs from dozens of available motifs, sometimes fusing the synthetic TRP to endogenous transcriptional effector domains (e.g. CRP from E. coli).

All the approaches listed above have been successfully applied to improve tolerance to stress, the production of target metabolites, and the use of alternative substrates in several bacterial species. Some of the resulting phenotypes, which were previously unattainable through classical strain improvement, were efficiently generated after a few rounds of selection. Furthermore, the selected mutants may possess multiple altered phenotypes. For instance, the best oxidative stress-tolerant E. coli mutant, obtained via engineering of CRP, also displayed enhanced thermotolerance at $48^{\circ} \mathrm{C}$ and resistance to organic solvents, thereby suggesting a significant mechanistic overlap in microbial stress responses. ${ }^{[69]}$

This article is protected by copyright. All rights reserved. 


\section{Engineering ribosomes and RNA polymerase}

Ribosome engineering has been widely used to optimize the production of antibiotics and to activate silent gene clusters involved in the biosynthesis of secondary metabolites in Actinobacteria. This technique, characterized by its remarkable simplicity, consists of the isolation of spontaneous mutants resistant to drugs that target bacterial ribosomes (e.g. streptomycin, gentamicin, kanamycin, and chloramphenicol) ${ }^{[70]}$ (Fig. 2F). Although the mechanism leading to the phenotypic variation in these mutants is not well understood, it is believed to be related to the activation of a stringent response that leads to elevated levels of protein synthesis during the late growth phase, beneficial for certain phenotypes (e.g. secondary metabolism). Mutants resistant to these antibiotics often exhibit deletions or point mutations within genes encoding ribosomal components (e.g. ribosomal proteins, ribosomal RNAs, or translation factors), thus altering the bacterial translation machinery. Similarly, the isolation of mutants resistant to rifampicin, which inhibits RNA polymerase, has been adopted to improve certain phenotypes. ${ }^{[71]}$ These mutants, endowed with a modified transcriptional machinery, often display RNA polymerase variants with enhanced affinity for the promoter region of certain genes related to secondary metabolism.

Both techniques described above (i.e. engineering ribosomes and RNA polymerase), allow for the identification of high-performance strains from drugresistant mutants with a high frequency (ranging from 5-40\%; see Table 2). These techniques have enabled overproduction of antibiotics in several Streptomyces species, $\alpha$-amylase and protease in Bacillus subtilis, and the improvement of tolerance to various aromatic compounds in the platform bacterium Pseudomonas putida. In addition, these approaches do not require any a priori genomic information or the use of mutagens, overcoming the accumulation of deleterious mutations in untargeted genomic regions. Furthermore, different concentrations and/or combinations of antibiotics can be used to isolate a collection of strains with a different spectrum of mutations, affecting the transcription and translation

This article is protected by copyright. All rights reserved. 
machinery and displaying altered phenotypic characteristics. For example, a 180fold increase in the production of actinorhodin in S. coelicolor has been achieved by the introduction of eight different drug-resistance mutations. ${ }^{[72]}$ However, the utility of these global approaches has been mostly circumscribed to the improvement of secondary metabolite biosynthesis, and only a few reports have focused on primary metabolites (e.g. vitamin $\mathrm{B}_{12}$ in Propionibacterium shermanii). ${ }^{[73]}$ Furthermore, since this type of techniques is based on the isolation of spontaneous mutants, its applicability may sometimes be restricted by the low frequency of spontaneous DNA mutations in bacteria. The adoption of targeted mutagenesis approaches is an alternative to overcome the practical limitations listed in this section.

\subsection{Targeted mutagenesis approaches}

\section{Combinatorial pathway engineering}

The construction of combinatorial libraries encoding metabolic routes is progressively becoming the choice for heterologous pathway optimization (e.g. to eliminate metabolic flux imbalances). The increasingly lower price of de novo DNA synthesis, the development of sophisticated DNA assembly technologies, and the standardization of genetic parts have notably accelerated the construction of libraries of variants à la carte. ${ }^{[74]}$ The combinatorial assembly of critical pathway and regulatory elements (e.g. plasmid backbones, promoters, ribosome binding sites, coding sequences, terminators) facilitates the simultaneous optimization at different regulation levels (e.g. number of gene copies, transcriptional and translational regulation, and coding sequences). For example, Pfleger et al. ${ }^{[75]}$ achieved a 7-fold increase in mevalonate production in engineered E. coli by generating libraries of tunable intergenic regions, combining various posttranscriptional control elements and screening for the desired relative expression levels in the resulting library.

This article is protected by copyright. All rights reserved. 
Alternatively, combinatorial libraries of metabolic pathways can be constructed by efficient homologous recombination techniques at the genome level (Fig. 3A). In vivo recombination-mediated genetic engineering (i.e. recombineering), based on homologous recombination events mediated by bacteriophage proteins such as RecET and $\lambda$ Red recombinases, have been employed successfully for genome editing in several bacterial species (e.g. E. coli, C. glutamicum, Mycobacterium smegmatis, and $P$. putida). ${ }^{[76]}$ In these techniques, linear double-stranded or singlestranded DNA substrates, equipped with homology arms that anneal the complementary strand in the replication fork, are used for targeted gene replacements, deletions, insertions, and inversions, or to introduce point mutations. An automated multiplex version of recombineering has been successfully implemented in E. coli, allowing for the construction of mutant libraries within a few days by simultaneously generating genetic variety in multiple target loci (automated multiplex genomic engineering, MAGE). The expression levels of 24 genes were optimized in parallel with MAGE to improve lycopene production in engineered $E$. coli, yielding better results than all the previously reported efforts combined. ${ }^{[77]}$ Improvements in this technique include automating the design of oligonucleotides and rendering multiplex recombineering easily traceable (e.g. trackable multiplex recombineering). ${ }^{[59 b]}$ Since recombineering systems currently available are not equally active in all bacterial systems, efforts should be also made to identify novel recombinases. The implementation of recombineering (at least when a multiplex approach is needed or when selectable markers are not used) requires the utilization of bacterial strains with impaired MMR or RecA activities, which might yield off-target mutations. Alternative approaches have been developed to circumvent this unwanted occurrence. ${ }^{[78]}$

A further step in these targeted manipulations is the coupling of recombineering with CRISPR-Cas9 technologies (i.e. CRISPR-Cas9-assisted recombineering). ${ }^{[79]}$ Recombineering mediates the repair of double-stranded DNA (dsDNA) breaks created by CRISPR-Cas9 through the integration of transformed dsDNA 
fragments, which can have degenerated positions to enable genetic variation. CRISPR-enabled trackable genome engineering (CREATE), which builds upon MAGE by incorporating CRISPR-Cas9 and barcoding technology, has been recently developed for this purpose. ${ }^{[80]}$ This technique combines the automated design and synthesis of target-specific sgRNA cassettes and dsDNA repair fragments, making it possible to mutate tens of thousands of genomic loci in parallel. The substantial improvement in throughput as compared with the previous methods is illustrated by the implementation of CREATE to optimize an isopropanol biosynthesis pathway in engineered E. coli by constructing and selecting a combinatorial library spanning $>1,000$ mutants. In addition, barcoding technology allows for simultaneous mapping of all mutations, thus facilitating the identification of beneficial mutations that confer phenotypes of interest in ALE. So far, CREATE has been only applied to E. coli; however, this approach is likely to work in other bacteria for which high-efficiency recombinases are available.

\section{CRISPR-guided, locus-specific random mutagenesis}

Novel and revolutionary tools to create locus-specific random mutations in bacterial genomes based on the CRISPR-Cas9 technology have been recently developed. These editing tools exploit the enzymatic activities of nucleasedeficient Cas9, avoiding the generation of dsDNA breaks that are lethal or severely toxic for many bacteria. Since no foreign DNA templates are required, these techniques may encounter less regulatory hurdles in industrial applications (Table 2).

A deaminase-mediated targeted mutagenesis tool was firstly developed for E. coli (Fig. 3B). In this case, a catalytically-inactivated Cas9 protein (dCas9) was fused to a cytosine deaminase activity and, together with a 20-nucleotide long sgRNA, allowed for the introduction of $\mathrm{C} \rightarrow \mathrm{T}$ substitutions at the target locus without compromising cell growth. ${ }^{[81]}$ The $\mathrm{C} \rightarrow \mathrm{T}$ substitutions were induced mainly within an approximately five-base window of target sequences on the protospacer adjacent

This article is protected by copyright. All rights reserved. 
motif-distal side, which can be shifted depending on the length of the sgRNA sequence. The use of a inhibitor of uracil DNA glycosylase, in combination with a degradation tag, resulted in a more robust mutagenesis tool-allowing for the simultaneous, multiplex editing of six different genes. As this methodology does not rely on any host-dependent factor, it is extensible to other relevant bacterial species, e.g. C. glutamicum and Pseudomonas sp. ${ }^{[82]}$

Another locus-specific DNA mutagenesis tool, termed EvolvR, has been recently developed for $E$. coli in order to diversify all nucleotides within a tunable window length (Fig. 3C) ${ }^{[83]}$ EvolvR consists of a CRISPR-guided Cas9 nickase (nCas9, which nicks the target locus) fused to a DNA polymerase (mediating error-prone nick translation). The construction and testing of multiple nickase-polymerase variants allowed for a wide range of targeted mutation rates (up to 7,770,000-fold larger than the mutagenesis rate observed in wild-type cells) and broadened the editing windows to up to 350 nucleotides.

\section{Exploiting the genetic variation of bacterial populations}

\subsection{Screening and selection technologies}

Irrespective of the methodology used to induce genetic variation within a bacterial population, efficient screening and selection methods are required to quickly fish out the MCF variants displaying the (enhanced) phenotype of interest (Fig. 1). Different technologies have been developed over the years to fulfill this purpose (Fig. 4). Selection in solid culture media has been extensively used in the improvement of industrial MCFs, since it facilitates the screening of a large number of mutants by visual inspection of plates (Fig. 4). The detection of color changes around the colonies (e.g. due to the formation of diffusing products or coupled enzymatic activities), and the differential growth in the presence of antibiotics, antimetabolites, or other toxic/stressor compounds, are commonly used criteria to select mutants displaying enhanced phenotypes. These plate-based screening assays, however, may be inefficient for the improvement of complex, 
multi-factorial phenotypes and they have the inherent risk of selecting phenotypes that are not easily reproducible in liquid media-which is the ultimate destination of most production MCFs.

Serial batch liquid cultivations, performed in simple flasks/tubes or in automated sequential batch reactors, can be used to select mutants with an increased maximum specific growth rate (Fig. 4). To ensure that the selection pressure is faster growth rate-instead of the myriad of other process factors, e.g. nutrient starvation or oxygen limitation-it is important that mid-exponential phase cultures are used to seed the subsequent batch. Alternatively, continuous cultivation in liquid media can be carried out to avoid variations in key culture parameters, e.g. growth rate, growth phase, $\mathrm{pH}$, or cell density; although these long-term cultures may suffer from microbial contamination. ${ }^{[84]}$ The most used continuous culture setup is the chemostat, which operates under limiting nutrient conditions that are fixed with the culture dilution rate to select mutants with higher affinity to the limiting substrate, e.g. mutants expressing high affinity transporters (Fig. 4). However, the ability of a microbial population selected under steady-state culture conditions to perform well under dynamic or nutrient-excess conditions (typical of industrial setups) may be compromised. To overcome some of these practical limitations, alternative continuous culture setups and dynamic selection regimes have been developed, e.g. accelerostats, auxostats, and turbidostats. Open, nonsterile bacterial fermentations have been also proposed as industrially-relevant and cost-effective alternatives to bioproduction. ${ }^{[85]}$ An emerging approach to identify fitter mutants within a population is the visualizing evolution in real-time (VERT), which can be applied to either serial batch liquid or continuous cultivations. ${ }^{[86]}$ The basis of VERT is the use of isogenic-but differentially labeled (typically with fluorescent proteins)—strains as the seed evolving population. As a beneficial mutant arises, the labelled sub-population to which the mutant belongs is expected to increase in proportion. The relative fractions of each of the colored sub-

This article is protected by copyright. All rights reserved. 
populations can be followed over time by using fluorescent-activated cell sorting (FACS).

An alternative cultivation technology for selecting slow-growing cells with a higher biomass yield is serial propagation in emulsion. ${ }^{[87]}$ By isolating individual cells in droplets, this strategy eliminates the competition for resources with neighboring cells, thus enabling the progressive enrichment of mutants with an increased number of viable offspring after several propagation rounds (Fig. 4). The utility of this concept was demonstrated by the individual compartmentalization of L. lactis. $^{\left[{ }^{88]}\right.}$ A similar approach, based on insulating bacteria in hollow fibers, enabled the progressive enrichment of $B$. subtilis mutants that secreted large amounts of enzyme into the culture medium used for selection. ${ }^{[89]}$ The intrinsic fluorescence properties of certain bioproducts, or the use of biocompatible fluorescent substrates that can be modified by endogenous enzymatic activities, ${ }^{[90]}$ allow for the straightforward selection of high-producer MCFs by FACS (Fig. 4). The development of small-molecule biosensors that enable the expression of fluorescent proteins in response to the intracellular accumulation of a target compound, has been also used for FACS-based sorting. ${ }^{\text {[90-91] }}$ These and other biosensors can be also applied for the screening of mutants displaying the (enhanced) phenotype of interest on agar plates or in high-throughput culture systems using different selectable phenotypic outputs (e.g. antibiotic resistance or LacZ activity). ${ }^{[92]}$

All the culture technologies described above have proved useful in selecting certain bacterial phenotypes; however, their application is mostly limited to traits that are directly or indirectly connected to growth. For this reason, the individual screening of mutant collections by means of small-scale fermentations coupled to the measurement of metabolites or products of interest in the culture broth, is still frequently performed to select for robust MCFs to be used in industrial applications (Fig. 4). The massive parallelization, automation, and miniaturization of these 
screening assays will be a key step to accelerate the characterization of mutant collections in the near future.

\subsection{Coupling phenotypes of interest to bacterial growth}

Linking any specific, relevant phenotype to a macroscopic parameter (e.g. growth rate or substrate affinity) and/or to the survival of individual mutants under selective culture conditions is still one of the biggest challenges in industrial biotechnology-especially if the biosynthesis of the target compound imposes a metabolic burden on the MCFs and impairs their growth. To overcome this issue, several rational experimental design and technological approaches are being developed, as indicated below.

Growth-coupling production strategies have become particularly relevant for Systems Metabolic Engineering over the past decade. ${ }^{[93]}$ The central goal of these approaches is to render the biosynthesis of a desired metabolite essential for bacterial growth (Fig. 5). The formation of the target metabolite thus becomes an integral part of the MCF metabolic network, making production the very driving force of bacterial growth. Growth-coupled MCFs for efficient production can be designed in a such a way that the synthesis of the desired metabolite is essential to attain maximal growth rate or to confer the ability to grow under a restrictive condition. In most cases, further improvement of such MCFs can be achieved through ALE by increasingly selecting for maximum growth. Examples of growthcoupling strategies typically include the targeted manipulation of native metabolism, the introduction of heterologous reactions to force coupling, the use of biosensors to tie cell survival to increases in the concentration of the target metabolite, and by manipulating the culture conditions to favor the growth of efficient producers. ${ }^{[94]}$ A major challenge in the near future is to generalize these growth-coupling strategies in order to be applicable to more products, both native and heterologous, without the need of implementing specialized selection systems for each metabolite in a case-by-case fashion. In addition, the appearance of

This article is protected by copyright. All rights reserved. 
selection escapers (i.e. non-producing mutants that are able to survive even in the presence of the selective pressure) and the difficulty to implement rational approaches across all bacterial hosts (especially non-model bacteria), make the screening and testing of individual mutants still necessary-resulting in significant investment of resources and time. Yet, the information gathered from these experiments can be used to engineer naïve strains as indicated in the next section.

\subsection{Reverse engineering of relevant phenotypes in bacteria}

As indicate before, an essential (and challenging) part of the process of obtaining industrially-relevant phenotypes in bacterial MCFs is the identification of the genotype-to-phenotype relationships. The best performing variants, isolated during the screening and selection steps described in the previous sections, can either be used directly for production purposes and/or can be further optimized in new cycles of improvement as needed (Fig. 1). However, the investigation and exploration of genotype-to-phenotype relationships enable novel rational strain designs (i.e. reverse engineering). Evolved populations and/or selected mutant strains with enhanced performance can be characterized using whole-genome sequencing and Systems Biology tools, with the ultimate goal of identifying causal mutations, uncovering selection escapers, and unravelling cell mechanisms leading to robust phenotypes. The beneficial mutations identified during the process are then implemented into clean, background production strains (i.e. naïve strains) — which, in some cases, harbor other features of interest and lack detrimental or neutral mutations accumulated during the evolution process (Fig. 1). Again, the combination of different mutations (usually in a non-linear fashion) usually leads to the phenotypes of interest, which would be difficult to predict a priori. A major step forward in this sense has been the creation of a database of $>11,000$ mutations found in several ALE experiments that can be used for reverse engineering a wide spectrum of industrially-relevant phenotypes. ${ }^{[95]}$

This article is protected by copyright. All rights reserved. 


\section{Conclusion and the way ahead}

The examples surveyed in this review illustrate the complex dynamic interactions in cellular systems that often hinder industrial applications of Metabolic Engineering endeavors. Although the final objective of Systems Metabolic Engineering is the rational optimization of industrially-relevant phenotypes on MCFs, the need for comprehensive molecular or functional knowledge and the availability of a dedicated Synthetic Biology toolbox are still major hurdles standing on the way towards purposefully engineering non-model bacteria. The implementation of methodologies based on the core engineering principle of natural evolution (i.e. genetic variation and selection) has proven to be a suitable alternative for optimizing the performance of industrial MCFs.

The development of efficient techniques for manipulating the nature and rate of DNA mutations, both globally and locally has simplified the construction of combinatorial libraries of mutants and the genetic diversification of bacterial populations. Novel, broad mutational landscapes that are not available in Naturedue partly to the conservative nature of the genetic code and the usually low mutation rates - can be accessed by applying these techniques. Multiple screening and selection technologies are also available for isolating high-performance mutants from genetically-diverse populations. Emerging microfluidic technologies will also drive a transition to automation, parallelization, and miniaturization of many screening assays. ${ }^{[96]}$ An often overlooked aspect of the whole process is the scaling-up of fermentations using engineered MCFs, including critical performance indicators such as catalytic durability, and genetic stability and evolvability. ${ }^{[97]}$ Although most of the (narrow) literature available on these matters deals with planktonic bacteria growing in liquid cultures, the same questions are likewise relevant for alternative cultivation setups, such as catalytic biofilms. ${ }^{[98]}$ Likewise, evolutionary trajectories in multi-species, synthetic microbial consortia ${ }^{[99]}$ are a fascinating challenge to tackle in the future.

This article is protected by copyright. All rights reserved. 
Finally, and although most of the bioproduction strategies implemented thus far are restricted to a handful of relatively simple products, emerging trends in biotechnological production rely on the biosynthesis of compounds that cannot be easily obtained by other means. The inclusion of chemical elements that are seldom (if at all) found in biological systems (e.g. boron, silicon, and halogens) is a particularly attractive feature to explore in the near future. ${ }^{[100]}$ The tools and approaches discussed in this article will become essential enabling technologies to engineer phenotypes based on novel, synthetic biochemistries-since tying novel, non-natural reactions involving new-to-Nature metabolites requires multi-level MCFs engineering. By taking full advantage of a combination of (natural and synthetic) genetic variability, ALE, and automated screening, the next generation of MCFs will allow for the exploration of the untapped biochemical landscapeexpanding the current boundaries of bioproduction beyond the customary compounds in the current industrial production pipeline. Data integration and exploitation, and process optimization in these Metabolic Engineering designs, supported by the increasingly expanding field of artificial intelligence, ${ }^{[101]}$ will become critical for establishing industrially-relevant phenotypes in bacterial cell factories - and to expand our understanding of the genotype-to-phenotype relationship underlying such features.

\section{Acknowledgements}

The authors wish to thank Prof. V. de Lorenzo (CNB-CSIC, Spain) for enlightening discussions. The financial support from The Novo Nordisk Foundation (grants NNF10CC1016517 and LiFe, NNF18OC0034818), the Danish Council for Independent Research (SWEET, DFF-Research Project 8021-00039B), and the European Union's Horizon 2020 Research and Innovation Programme under grant agreement No. 814418 (SinFonia) to P.I.N. is gratefully acknowledged. L.F.C. is supported by the European Union's Horizon 2020 Research and Innovation Programme under the Marie Skłodowska-Curie grant agreement No. 713683 (COFUNDfellowsDTU).

This article is protected by copyright. All rights reserved. 


\section{Conflict of interest}

The authors declare no financial or commercial conflict of interest.

\section{References}

[1] M. J. Johnson, Annu. Rev. Microbiol. 1947, 1, 159-172.

[2] a) K. Buchholz, J. Collins, Appl. Microbiol. Biotechnol. 2013, 97, 37473762; b) A. L. Demain, Science 1981, 214, 987-995.

[3] J. Nielsen, Biotechnol. J. 2019, In press, DOI: 10.1002/biot.201800421.

[4] K. Timmis, W. M. de Vos, J. L. Ramos, S. E. Vlaeminck, A. Prieto, A. Danchin, W. Verstraete, V. de Lorenzo, S. Y. Lee, H. Brüssow, J. K. Timmis, B. K. Singh, Microb. Biotechnol. 2017, 10, 984-987.

[5] K. Timmis, V. de Lorenzo, W. Verstraete, J. L. Ramos, A. Danchin, H. Brüssow, B. K. Singh, J. K. Timmis, Microb. Biotechnol. 2017, 10, 11371144.

[6] a) P. Calero, P. I. Nikel, Microb. Biotechnol. 2019, 12, 98-124; b) P. I. Nikel, V. de Lorenzo, Metab. Eng. 2018, 50, 142-155; c) S. F. Yuan, H. S. Alper, Microb. Cell Fact. 2019, 18, 46; d) P. F. Xia, H. Ling, J. L. Foo, M. W. Chang, Biotechnol. J. 2019, In press, DOI: 10.1002/biot.201800496; e) P. I. Nikel, E. Martínez-García, V. de Lorenzo, Nat. Rev. Microbiol. 2014, 12, 368-379; f) N. I. López, M. J. Pettinari, P. I. Nikel, B. S. Méndez, Adv. Appl. Microbiol. 2015, 93, 93-106; g) P. I. Nikel, V. de Lorenzo, New Biotechnol. 2014, 31, 562-571.

[7] V. de Lorenzo, J. Couto, Microb. Biotechnol. 2019, 12, 32-34.

This article is protected by copyright. All rights reserved. 
[8] a) C. N. S. Santos, G. Stephanopoulos, Curr. Opin. Chem. Biol. 2008, 12, 168-176; b) M. Gustavsson, S. Y. Lee, Microb. Biotechnol. 2016, 9, 610617; c) R. Patnaik, Biotechnol. Prog. 2008, 24, 38-47; d) S. van Dien, Curr. Opin. Biotechnol. 2013, 24, 1061-1068; e) Z. Gong, J. Nielsen, Y. J. Zhou, Biotechnol. J. 2017, 12, 1700014.

[9] C. Barreiro, J. F. Martín, C. García-Estrada, J. Biomed. Biotechnol. 2012, 2012, 105109.

[10] a) J. E. Bailey, Science 1991, 252, 1668-1675; b) G. Stephanopoulos, J. J. Vallino, Science 1991, 252, 1675-1681.

[11] A. Danchin, FEBS Lett. 2012, 586, 2129-2137.

[12] a) G. S. Hossain, S. P. Nadarajan, L. Zhang, T. K. Ng, J. L. Foo, H. Ling, W. J. Choi, M. W. Chang, Front. Microbiol. 2018, 9, 155; b) L. Martinelli, P. I. Nikel, Microb. Biotechnol. 2019, 12, 187-190; c) J. Becker, C. Wittmann, Curr. Opin. Microbiol. 2018, 45, 180-188; d) A. M. Davy, H. F. Kildegaard, M. R. Andersen, Cell Syst. 2017, 4, 262-275; e) J. Nielsen, J. D. Keasling, Cell 2016, 164, 1185-1197; f) A. Biz, S. Proulx, Z. Xu, K. Siddartha, A. M. Indrayanti, R. Mahadevan, Biotechnol. Adv. 2019, In press, DOI: 10.1016/j.biotechadv.2019.1004.1001.

[13] a) K. R. Choi, W. D. Jang, D. Yang, J. S. Cho, D. Park, S. Y. Lee, Trends Biotechnol. 2019, In press, DOI: 10.1016/j.tibtech.2019.1001.1003; b) J. W. Lee, D. Na, J. M. Park, J. Lee, S. Choi, S. Y. Lee, Nat. Chem. Biol. 2012, 8, 536-546; c) S. Y. Lee, H. U. Kim, Nat. Biotechnol. 2015, 33, 1061-1072; d) V. de Lorenzo, K. L. Prather, G. Q. Chen, E. O'Day, C. von Kameke, D. A. Oyarzún, L. Hosta-Rigau, H. Alsafar, C. Cao, W. Ji, H. Okano, R. J. Roberts, M. Ronaghi, K. Yeung, F. Zhang, S. Y. Lee, EMBO Rep. 2018, 19, e45658; e) Y. Lee, I. J. Cho, S. Y. Choi, S. Y. Lee, Biotechnol. J. 2019, In press, DOI: 10.1002/biot.201800426.

This article is protected by copyright. All rights reserved. 
[14] a) J. Becker, O. Zelder, S. Häfner, H. Schröder, C. Wittmann, Metab. Eng. 2011, 13, 159-168; b) C. J. Paddon, P. J. Westfall, D. J. Pitera, K. Benjamin, K. Fisher, D. McPhee, M. D. Leavell, A. Tai, A. Main, D. Eng, D. R. Polichuk, K. H. Teoh, D. W. Reed, T. Treynor, J. Lenihan, M. Fleck, S. Bajad, G. Dang, D. Dengrove, D. Diola, G. Dorin, K. W. Ellens, S. Fickes, J. Galazzo, S. P. Gaucher, T. Geistlinger, R. Henry, M. Hepp, T. Horning, T. Iqbal, H. Jiang, L. Kizer, B. Lieu, D. Melis, N. Moss, R. Regentin, S. Secrest, H. Tsuruta, R. Vazquez, L. F. Westblade, L. Xu, M. Yu, Y. Zhang, L. Zhao, J. Lievense, P. S. Covello, J. D. Keasling, K. K. Reiling, N. S. Renninger, J. D. Newman, Nature 2013, 496, 528-532; c) H. Yim, R. Haselbeck, W. Niu, C. Pujol-Baxley, A. Burgard, J. Boldt, J. Khandurina, J. D. Trawick, R. E. Osterhout, R. Stephen, J. Estadilla, S. Teisan, H. B. Schreyer, S. Andrae, T. H. Yang, S. Y. Lee, M. J. Burk, S. van Dien, Nat. Chem. Biol. 2011, 7, 445-452; d) S. H. Park, H. U. Kim, T. Y. Kim, J. S. Park, S. S. Kim, S. Y. Lee, Nat. Commun. 2014, 5, 4618.

[15] L. P. Yu, F. Q. Wu, G. Q. Chen, Biotechnol. J. 2019, In press, DOI: 10.1002/biot.201800437.

[16] E. Freed, J. Fenster, S. L. Smolinski, J. Walker, C. A. Henard, R. Gill, C. A. Eckert, Biotechnol. Bioeng. 2018, 115, 2120-2138.

[17] J. Xia, G. Wang, J. Lin, Y. Wang, J. Chu, Y. Zhuang, S. Zhang, Adv. Biochem. Eng. Biotechnol. 2016, 152, 137-151.

[18] a) R. G. Stella, J. Wiechert, S. Noack, J. Frunzke, Biotechnol. J. 2019, In press, DOI: 10.1002/biot.201800444; b) B. van den Bergh, T. Swings, M. Fauvart, J. Michiels, Microbiol. Mol. Biol. Rev. 2018, 82, e00008-00018.

[19] a) U. Sauer, in Metabolic Engineering (Eds.: J. Nielsen, L. Eggeling, J. Dynesen, M. Gárdonyi, R. T. Gill, A. A. de Graaf, B. Hahn-Hägerdal, L. J. Jönsson, C. Khosla, R. Licari, R. McDaniel, M. McIntyre, C. Miiller, J.

This article is protected by copyright. All rights reserved. 
Nielsen, R. R. Cordero Otero, H. Sahm, U. Sauer, D. E. Stafford, G. Stephanopoulos, C. E. Wahlbom, K. S. Yanagimachi, W. H. van Zyl), Springer, Berlin, Germany, 2001, pp. 129-169; b) T. E. Sandberg, C. J. Lloyd, B. Ø. Palsson, A. M. Feist, Appl. Environ. Microbiol. 2017, 83, e00410-00417.

[20] M. Dragosits, D. Mattanovich, Microb. Cell Fact. 2013, 12, 64.

[21] R. Mans, J. G. Daran, J. T. Pronk, Curr. Opin. Biotechnol. 2018, 50, 47-56.

[22] H. Bachmann, J. T. Pronk, M. Kleerebezem, B. Teusink, Curr. Opin. Biotechnol. 2015, 32, 1-7.

[23] a) T. Jin, Y. Chen, L. R. Jarboe, in Biotechnology for biofuel production and optimization (Eds.: C. A. Eckert, C. T. Trinh), Elsevier, Amsterdam, 2016, pp. 265-290; b) R. A. LaCroix, B. Ø. Palsson, A. M. Feist, Appl. Environ. Microbiol. 2017, 83, e03115-03116; c) D. Shepelin, A. S. L. Hansen, R. M. Lennen, H. Luo, M. J. Herrgård, Genes 2018, 9, 249; d) Z. Zhu, J. Zhang, X. Ji, Z. Fang, Z. Wu, J. Chen, G. Du, Appl. Microbiol. Biotechnol. 2018, 102, 4615-4627; e) C. P. Long, J. E. Gonzalez, A. M. Feist, B. Ø. Palsson, M. R. Antoniewicz, Proc. Natl. Acad. Sci. USA 2018, 115, 222-227.

[24] a) M. Jeschek, D. Gerngross, S. Panke, Curr. Opin. Biotechnol. 2017, 47, 142-151; b) W. Liu, R. Jiang, Appl. Microbiol. Biotechnol. 2015, 99, 20932104; c) H. Lu, J. C. Villada, P. K. H. Lee, Trends Biotechnol. 2019, 37, 152-166.

[25] a) M. Bosse, H. J. Megens, M. F. L. Derks, A. M. R. de Cara, M. A. M. Groenen, Evol. Appl. 2018, 12, 6-17; b) R. S. Meyer, M. D. Purugganan, Nat. Rev. Genet. 2013, 14, 840-852.

This article is protected by copyright. All rights reserved. 
[26] S. Maisnier-Patin, J. R. Roth, Cold Spring Harb. Perspect. Biol. 2015, 7, a018176.

[27] a) J. W. Drake, Proc. Natl. Acad. Sci. USA 1991, 88, 7160-7164; b) G. I. Lang, A. W. Murray, Genetics 2008, 178, 67-82.

[28] a) D. Pérez-Pantoja, P. I. Nikel, M. Chavarría, V. de Lorenzo, PLoS Genet. 2013, 9, e1003764; b) P. Dvořák, P. I. Nikel, J. Damborský, V. de Lorenzo, Biotechnol. Adv. 2017, 35, 845-866.

[29] a) Ö. Akkaya, P. I. Nikel, D. Pérez-Pantoja, V. de Lorenzo, Environ. Microbiol. 2019, 21, 314-326; b) Ö. Akkaya, D. Pérez-Pantoja, B. Calles, P. I. Nikel, V. de Lorenzo, mBio 2018, 9, e01512-01518.

[30] a) P. L. Foster, Methods Enzymol. 2006, 409, 195-213; b) A. Kodym, R. Afza, Methods Mol. Biol. 2003, 236, 189-204.

[31] X. Zhang, X. F. Zhang, H. P. Li, L. Y. Wang, C. Zhang, X. H. Xing, C. Y. Bao, Appl. Microbiol. Biotechnol. 2014, 98, 5387-5396.

[32] J. P. Horst, T. H. Wu, M. G. Marinus, Trends Microbiol. 1999, 7, 29-36.

[33] a) Z. Bódi, Z. Farkas, D. Nevozhay, D. Kalapis, V. Lázár, B. Csörgő, A. Nyerges, B. Szamecz, G. Fekete, B. Papp, H. Araújo, J. L. Oliveira, G. Moura, M. A. S. Santos, T. Székely, G. Balázsi, C. Pál, PLoS Biol. 2017, 15, e2000644; b) K. Umenhoffer, T. Fehér, G. Balikó, F. Ayaydin, J. Pósfai, F. R. Blattner, G. Pósfai, Microb. Cell Fact. 2010, 9, 38.

[34] a) A. Oliver, F. Baquero, J. Blázquez, Mol. Microbiol. 2002, 43, 16411650; b) T. Swings, B. van den Bergh, S. Wuyts, E. Oeyen, K. Voordeckers, K. J. Verstrepen, M. Fauvart, N. Verstraeten, J. Michiels, eLife 2017, 6, e22939.

[35] A. Greener, M. Callahan, B. Jerpseth, Mol. Biotechnol. 1997, 7, 189-195.

This article is protected by copyright. All rights reserved. 
[36] a) D. Emlyn-Jones, G. D. Price, T. J. Andrews, Appl. Environ. Microbiol. 2003, 69, 6427-6433; b) A. Endo, M. Sasaki, A. Maruyama, Y. Kurusu, Biosci. Biotechnol. Biochem. 2006, 70, 2357-2362; c) G. Luan, Z. Cai, F. Gong, H. Dong, Z. Lin, Y. Zhang, Y. Li, Protein Cell 2013, 4, 854-862; d) T. J. Overbeck, D. L. Welker, J. E. Hughes, J. L. Steele, J. R. Broadbent, Appl. Environ. Microbiol. 2017, 83, e01120-01117; e) O. Selifonova, F. Valle, V. Schellenberger, Appl. Environ. Microbiol. 2001, 67, 3645-3649.

[37] B. Csörgő, A. Nyerges, G. Posfai, T. Fehér, Curr. Opin. Microbiol. 2016, 33, 113-122.

[38] a) A. H. Badran, D. R. Liu, Nat. Commun. 2015, 6, 8425; b) L. Zhu, Y. Li, Z. Cai, Biotechnol. Biofuels 2015, 8, 93.

[39] G. Luan, Z. Cai, Y. Li, Y. Ma, Biotechnol. Biofuels 2013, 6, 137.

[40] G. Luan, G. Bao, Z. Lin, Y. Li, Z. Chen, Y. Li, Z. Cai, New Biotechnol. 2015, 32, 732-738.

[41] H. H. Chou, J. D. Keasling, Nat. Commun. 2013, 4, 2595.

[42] H. L. Pham, A. Wong, N. Chua, W. S. Teo, W. S. Yew, M. W. Chang, Nat. Commun. 2017, 8, 411.

[43] a) R. Patnaik, S. Louie, V. Gavrilovic, K. Perry, W. P. Stemmer, C. M. Ryan, S. del Cardayré, Nat. Biotechnol. 2002, 20, 707-712; b) Y. X. Zhang, K. Perry, V. A. Vinci, K. Powell, W. P. Stemmer, S. B. del Cardayré, Nature 2002, 415, 644-646.

[44] a) J. Gong, H. Zheng, Z. Wu, T. Chen, X. Zhao, Biotechnol. Adv. 2009, 27, 996-1005; b) T. A. Magocha, H. Zabed, M. Yang, J. Yun, H. Zhang, X. Qi, Biores. Technol. 2018, 257, 281-289; c) D. Biot-Pelletier, V. J. J. Martin, Appl. Microbiol. Biotechnol. 2014, 98, 3877-3887.

This article is protected by copyright. All rights reserved. 
[45] a) M. Dai, S. D. Copley, Appl. Environ. Microbiol. 2004, 70, 2391-2397; b)

L. H. Reyes, M. P. Almario, J. Winkler, M. M. Orozco, K. C. Kao, Metab. Eng. 2012, 14, 579-590; c) L. Yi, Q. Peng, D. Liu, L. Zhou, C. Tang, Y. Zhou, L. Chai, Environ. Technol. 2018, 1-9.

[46] J. Merritt, J. S. Edwards, Metab. Eng. 2004, 6, 212-219.

[47] P. Calero, S. I. Jensen, K. Bojanovič, R. M. Lennen, A. Koza, A. T. Nielsen, Biotechnol Bioeng 2018, 115, 762-774.

[48] T. Baba, T. Ara, M. Hasegawa, Y. Takai, Y. Okumura, M. Baba, K. A. Datsenko, M. Tomita, B. L. Wanner, H. Mori, Mol. Syst. Biol. 2006, 2, 2006.0008 .

[49] a) E. Martínez-García, V. de Lorenzo, Curr. Opin. Biotechnol. 2017, 47, 120-132; b) N. T. Wirth, E. Kozaeva, P. I. Nikel, Microb. Biotechnol. 2019, In press, DOI: 10.1111/1751-7915.13396; c) D. C. Volke, J. Turlin, V. Mol, P. I. Nikel, Microb. Biotechnol. 2019, In press, DOI: 10.1111/17517915.13383; d) K. C. Murphy, in EcoSal Plus · Domain 7: Genetics and Genetic Tools, 2016/05/26 ed. (Ed.: J. M. Slauch), ASM Press, Washington D.C., USA, 2016, pp. DOI: 10.1128/ecosalplus.ESP-0011-2015.

[50] L. S. Qi, M. H. Larson, L. A. Gilbert, J. A. Doudna, J. S. Weissman, A. P. Arkin, W. A. Lim, Cell 2013, 152, 1173-1183.

[51] a) L. Cui, A. Vigouroux, F. Rousset, H. Varet, V. Khanna, D. Bikard, Nat. Commun. 2018, 9, 1912; b) X. Liu, C. Gallay, M. Kjos, A. Domenech, J. Slager, S. P. van Kessel, K. Knoops, R. A. Sorg, J. R. Zhang, J. W. Veening, Mol. Syst. Biol. 2017, 13, 931; c) J. M. Peters, A. Colavin, H. Shi, T. L. Czarny, M. H. Larson, S. Wong, J. S. Hawkins, C. H. S. Lu, B. M. Koo, E. Marta, A. L. Shiver, E. H. Whitehead, J. S. Weissman, E. D. Brown, L. S. Qi, K. C. Huang, C. A. Gross, Cell 2016, 165, 1493-1506; d) F. Rousset, L. Cui, E. Siouve, C. Becavin, F. Depardieu, D. Bikard, PLoS 
Genet. 2018, 14, e1007749; e) T. Wang, C. Guan, J. Guo, B. Liu, Y. Wu, Z. Xie, C. Zhang, X. H. Xing, Nat. Commun. 2018, 9, 2475.

[52] J. M. Peters, B. M. Koo, R. Patino, G. E. Heussler, C. C. Hearne, J. Qu, Y. F. Inclan, J. S. Hawkins, C. H. S. Lu, M. R. Silvis, M. M. Harden, H. Osadnik, J. E. Peters, J. N. Engel, R. J. Dutton, A. D. Grossman, C. A. Gross, O. S. Rosenberg, Nat. Microbiol. 2019, 4, 244-250.

[53] M. Kitagawa, T. Ara, M. Arifuzzaman, T. Ioka-Nakamichi, E. Inamoto, H. Toyonaga, H. Mori, DNA Res. 2005, 12, 291-299.

[54] a) S. Gahlot, A. Joshi, P. Singh, R. Tuteja, M. Dua, A. Jogawat, M. Kumar, S. Raj, V. Dayaman, A. K. Johri, N. Tuteja, World J. Microbiol. Biotechnol. 2015, 31, 1195-1209; b) T. A. Tomko, M. J. Dunlop, Biotechnol. Biofuels 2015, 8, 165.

[55] Y. S. Jin, G. Stephanopoulos, Metab. Eng. 2007, 9, 337-347.

[56] J. R. Borden, S. W. Jones, D. Indurthi, Y. Chen, E. T. Papoutsakis, Metab. Eng. 2010, 12, 268-281.

[57] S. A. Nicolaou, S. M. Gaida, E. T. Papoutsakis, Nucleic Acids Res. 2011, 39, e152.

[58] a) M. D. Lynch, T. Warnecke, R. T. Gill, Nat. Methods 2007, 4, 87-93; b) V. K. Mutalik, P. S. Novichkov, M. N. Price, T. K. Owens, M. Callaghan, S. Carim, A. M. Deutschbauer, A. P. Arkin, Nat. Commun. 2019, 10, 308; c) T. van Opijnen, A. Camilli, Nat. Rev. Microbiol. 2013, 11, 435-442.

[59] a) A. D. Garst, M. C. Bassalo, G. Pines, S. A. Lynch, A. L. HalwegEdwards, R. Liu, L. Liang, Z. Wang, R. Zeitoun, W. G. Alexander, R. T. Gill, Nat. Biotechnol. 2017, 35, 48-55; b) J. R. Warner, P. J. Reeder, A. Karimpour-Fard, L. B. Woodruff, R. T. Gill, Nat. Biotechnol. 2010, 28, 856-862.

This article is protected by copyright. All rights reserved. 
[60] a) Z. Lin, Y. Zhang, J. Wang, Biotechnol. Adv. 2013, 31, 986-991; b) L. Tripathi, Y. Zhang, Z. Lin, Front. Bioeng. Biotechnol. 2014, 2, 33.

[61] A. S. N. Seshasayee, K. Sivaraman, N. M. Luscombe, in A handbook of transcription factors (Ed.: T. R. Hughes), Springer, Dordrecht, The Netherlands, 2011, pp. 7-23.

[62] a) H. Alper, G. Stephanopoulos, Metab. Eng. 2007, 9, 258-267; b) A. M. Lanza, H. S. Alper, in Synthetic gene networks: Methods and protocols (Eds.: W. Weber, M. Fussenegger), Humana Press, Totowa, New Jersey, USA, 2012, pp. 229-248.

[63] a) F. Tan, B. Wu, L. Dai, H. Qin, Z. Shui, J. Wang, Q. Zhu, G. Hu, M. He, Microb. Cell Fact. 2016, 15, 4; b) X. W. Guo, Y. Zhang, L. L. Li, X. Y. Guan, J. Guo, D. G. Wu, Y. F. Chen, D. G. Xiao, Biotechnol. Biofuels 2018, 11, 307.

[64] X. Gao, X. Yang, J. Li, Y. Zhang, P. Chen, Z. Lin, Microb. Cell Fact. 2018, $17,118$.

[65] H. Cao, J. Villatoro-Hernández, R. D. O. Weme, E. Frenzel, O. P. Kuipers, Metab. Eng. 2018, 49, 143-152.

[66] T. Chen, J. Wang, R. Yang, J. Li, M. Lin, Z. Lin, PLoS One 2011, 6, e16228.

[67] H. Wang, L. Yang, K. Wu, G. Li, Microb. Cell Fact. 2014, 13, 10.

[68] a) J. Y. Lee, B. H. Sung, B. J. Yu, J. H. Lee, S. H. Lee, M. S. Kim, M. D. Koob, S. C. Kim, Nucleic Acids Res. 2008, 36, e102; b) J. Y. Lee, K. S. Yang, S. A. Jang, B. H. Sung, S. C. Kim, Biotechnol. Bioeng. 2011, 108, 742-749; c) K. S. Park, Y. S. Jang, H. Lee, J. S. Kim, J. Bacteriol. 2005, 187, 5496-5499.

This article is protected by copyright. All rights reserved. 
[69] S. Basak, R. Jiang, PLoS One 2012, 7, e51179.

[70] K. Ochi, J. Antibiot. 2017, 70, 25-40.

[71] Y. Tanaka, K. Kasahara, Y. Hirose, K. Murakami, R. Kugimiya, K. Ochi, J. Bacteriol. 2013, 195, 2959-2970.

[72] G. Wang, T. Hosaka, K. Ochi, Appl. Environ. Microbiol. 2008, 74, 28342840.

[73] Y. Tanaka, K. Kasahara, M. Izawa, K. Ochi, Biosci. Biotechnol. Biochem. 2017, 81, 1636-1641.

[74] a) A. Casini, M. Storch, G. S. Baldwin, T. Ellis, Nat. Rev. Mol. Cell Biol. 2015, 16, 568-576; b) S. Kosuri, G. M. Church, Nat. Methods 2014, 11, 499-507; c) R. Silva-Rocha, E. Martínez-García, B. Calles, M. Chavarría, A. Arce-Rodríguez, A. de las Heras, A. D. Páez-Espino, G. DuranteRodríguez, J. Kim, P. I. Nikel, R. Platero, V. de Lorenzo, Nucleic Acids Res. 2013, 41, D666-D675; d) P. I. Nikel, V. de Lorenzo, J. Biotechnol. 2013, 163, 143-154; e) G. Durante-Rodríguez, V. de Lorenzo, P. I. Nikel, ACS Synth. Biol. 2018, 7, 2686-2697.

[75] B. F. Pfleger, D. J. Pitera, C. D. Smolke, J. D. Keasling, Nat. Biotechnol. 2006, 24, 1027-1032.

[76] a) Y. Huang, L. Li, S. Xie, N. Zhao, S. Han, Y. Lin, S. Zheng, Sci. Rep. 2017, 7, 7916; b) K. C. Murphy, K. Papavinasasundaram, C. M. Sassetti, in Mycobacteria protocols, Vol. 1285 (Eds.: T. Parish, D. M. Roberts), Humana Press, New York, USA, 2015, pp. 177-199; c) G. Pines, E. F. Freed, J. D. Winkler, R. T. Gill, ACS Synth. Biol. 2015, 4, 1176-1185; d) D. E. Ricaurte, E. Martínez-García, A. Nyerges, C. Pal, V. de Lorenzo, T. Aparicio, Microb. Biotechnol. 2018, 11, 176-188; e) J. A. Sawitzke, L. C. Thomason, N. Costantino, M. Bubunenko, S. Datta, D. L. Court, Methods

This article is protected by copyright. All rights reserved. 
Enzymol. 2007, 421, 171-199; f) K. A. Datsenko, B. L. Wanner, Proc. Natl. Acad. Sci. USA 2000, 97, 6640-6645; g) T. Aparicio, V. de Lorenzo, E. Martínez-García, Biotechnol. J. 2018, 13, e1700161.

[77] H. H. Wang, F. J. Isaacs, P. A. Carr, Z. Z. Sun, G. Xu, C. R. Forest, G. M. Church, Nature 2009, 460, 894-898.

[78] Á. Nyerges, B. Csörgő, I. Nagy, B. Bálint, P. Bihari, V. Lázár, G. Apjok, K. Umenhoffer, B. Bogos, G. Pósfai, C. Pál, Proc. Natl. Acad. Sci. USA 2016, 113, 2502-2507.

[79] a) W. Jiang, D. Bikard, D. Cox, F. Zhang, L. A. Marraffini, Nat. Biotechnol. 2013, 31, 233-239; b) Y. Jiang, B. Chen, C. Duan, B. Sun, J. Yang, S. Yang, Appl. Environ. Microbiol. 2015, 81, 2506-2514; c) C. R. Reisch, K. L. J. Prather, Sci. Rep. 2015, 5, 15096; d) C. Ronda, L. E. Pedersen, M. O. A. Sommer, A. T. Nielsen, Sci. Rep. 2016, 6, 19452.

[80] L. Liang, R. Liu, A. D. Garst, T. Lee, V. Sànchez i Nogué, G. T. Beckham, R. T. Gill, Metab. Eng. 2017, 41, 1-10.

[81] S. Banno, K. Nishida, T. Arazoe, H. Mitsunobu, A. Kondo, Nat. Microbiol. 2018, 3, 423-429.

[82] a) W. Chen, Y. Zhang, Y. Zhang, Y. Pi, T. Gu, L. Song, Y. Wang, Q. Ji, iScience 2018, 6, 222-231; b) Y. Wang, Y. Liu, J. Liu, Y. Guo, L. Fan, X. Ni, X. Zheng, M. Wang, P. Zheng, J. Sun, Y. Ma, Metab. Eng. 2018, 47, 200-210.

[83] S. O. Halperin, C. J. Tou, E. B. Wong, C. Modavi, D. V. Schaffer, J. E. Dueber, Nature 2018, 560, 248-252.

[84] T. Li, X. B. Chen, J. C. Chen, Q. Wu, G. Q. Chen, Biotechnol. J. 2014, 9, 1503-1511.

This article is protected by copyright. All rights reserved. 
[85] G. Q. Chen, X. R. Jiang, Curr. Opin. Biotechnol. 2018, 50, 94-100.

[86] a) K. C. Kao, G. Sherlock, Nat. Genet. 2008, 40, 1499; b) L. Reyes, J. Winkler, K. Kao, Front. Microbiol. 2012, 3, 198.

[87] H. Bachmann, F. J. Bruggeman, D. Molenaar, F. Branco dos Santos, B. Teusink, Curr. Opin. Microbiol. 2016, 31, 109-115.

[88] H. Bachmann, M. Fischlechner, I. Rabbers, N. Barfa, F. Branco dos Santos, D. Molenaar, B. Teusink, Proc. Natl. Acad. Sci. USA 2013, 110, 1430214307.

[89] D. Naki, C. Paech, G. Ganshaw, V. Schellenberger, Appl. Microbiol. Biotechnol. 1998, 49, 290-294.

[90] J. L. Lin, J. M. Wagner, H. S. Alper, Biotechnol. Adv. 2017, 35, 950-970.

[91] a) A. C. Carpenter, I. T. Paulsen, T. C. Williams, Genes 2018, 9, 375; b) T. C. Williams, I. S. Pretorius, I. T. Paulsen, Trends Biotechnol. 2016, 34, 371-381.

[92] a) Y. Liu, Y. Liu, M. Wang, Front. Microbiol. 2017, 8, 2012; b) S. A. Morgan, D. C. Nadler, R. Yokoo, D. F. Savage, Curr. Opin. Chem. Biol. 2016, 35, 150-158.

[93] a) S. Aslan, E. Noor, A. Bar-Even, Biochem. J. 2017, 474, 3935-3950; b) Y. S. Tai, M. Xiong, P. Jambunathan, J. Wang, J. Wang, C. Stapleton, K. Zhang, Nat. Chem. Biol. 2016, 12, 247-253; c) A. von Kamp, S. Klamt, Nat. Commun. 2017, 8, 15956; d) H. Luo, A. S. L. Hansen, L. Yang, K. Schneider, M. Kristensen, U. Christensen, H. B. Christensen, B. Du, E. Özdemir, A. M. Feist, J. D. Keasling, M. K. Jensen, M. J. Herrgård, B. Ø. Palsson, PLoS Biol. 2019, 17, e2007050; e) H. V. Dinh, Z. A. King, B. Ø. Palsson, A. M. Feist, Metab. Eng. Commun. 2018, 7, e00080.

This article is protected by copyright. All rights reserved. 
[94] a) K. Jantama, M. J. Haupt, S. A. Svoronos, X. Zhang, J. C. Moore, K. T. Shanmugam, L. O. Ingram, Biotechnol. Bioeng. 2008, 99, 1140-1153; b) Y. Lv, S. Qian, G. Du, J. Chen, J. Zhou, P. Xu, Metab. Eng. 2019, 54, 109116.

[95] P. V. Phaneuf, D. Gosting, B. Ø. Palsson, A. M. Feist, Nucleic Acids Res. 2019, 47, D1164-d1171.

[96] J. Riordon, D. Sovilj, S. Sanner, D. Sinton, E. W. K. Young, Trends Biotechnol. 2019, 37, 310-324.

[97] M. H. H. Nørholm, Microb. Biotechnol. 2019, 12, 35-37.

[98] a) D. C. Volke, P. I. Nikel, Adv. Biosyst. 2018, 2, 1800111; b) I. Benedetti, V. de Lorenzo, P. I. Nikel, Metab Eng 2016, 33, 109-118.

[99] N. S. McCarty, R. Ledesma-Amaro, Trends Biotechnol. 2019, 37, 181-197.

[100] F. H. Arnold, Angew. Chem. Int. Ed. Engl. 2018, 57, 4143-4148.

[101] A. L. Oliveira, Biotechnol. J. 2019, In press, DOI: 10.1002/biot.201800613.

[102] a) P. Rugbjerg, N. Myling-Petersen, A. Porse, K. Sarup-Lytzen, M. O. A. Sommer, Nat. Commun. 2018, 9, 787; b) P. Rugbjerg, K. Sarup-Lytzen, M. Nagy, M. O. A. Sommer, Proc. Natl. Acad. Sci. USA 2018, 115, 23472352.

[103] M. Jeschek, D. Gerngross, S. Panke, Nat. Commun. 2016, 7, 11163.

[104] H. Zheng, X. Wang, L. P. Yomano, R. D. Geddes, K. T. Shanmugam, L. O. Ingram, Appl. Environ. Microbiol. 2013, 79, 3202-3208.

This article is protected by copyright. All rights reserved. 


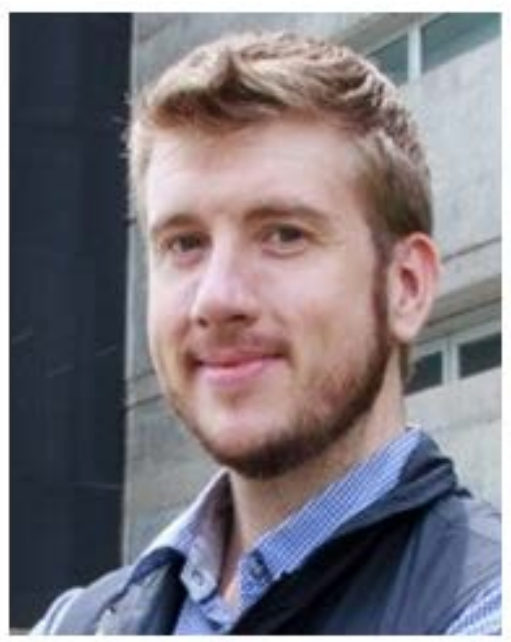

Pablo I. Nikel is a Senior Researcher and head of the Systems Environmental Microbiology group at the Novo Nordisk Foundation Center for Biosustainability (Denmark). After receiving a B.Sc. in Biotechnology and a Ph.D. in Molecular Biology and Biotechnology in Buenos Aires (Argentina), he moved to Spain to pursue his interests in metabolic engineering as a post-doctoral fellow financed by the European Molecular Biology Organization and the Marie Skłodowska-Curie Actions of the European Union. Since 2017, his multidisciplinary team combines systems and synthetic biology approaches to harness the catalytic potential of environmental bacteria for the sustainable production of novel added-value biochemicals via synthetic metabolisms.

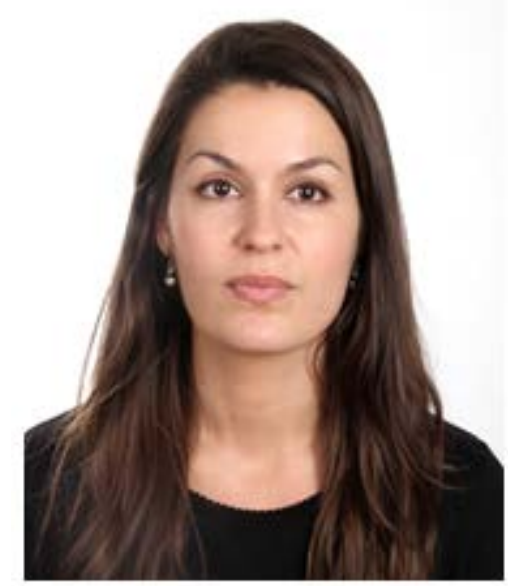

Lorena Fernández-Cabezón is a H.C. Ørsted COFUND post-doctoral fellow in the Systems Environmental Microbiology group at The Novo Nordisk Foundation Center for Biosustainability (Denmark). She obtained her Ph.D. in Biochemistry, Molecular Biology, and Biomedicine from the Complutense University of Madrid (Spain). During her Ph.D. thesis, developed at CIB-CSIC, she studied catabolic pathways in Mycobacterium smegmatis involved in steroid degradation. She received her B.Sc. in Biotechnology from the University of León, and her M.Sc. in

This article is protected by copyright. All rights reserved. 
Advanced Biotechnology from the Autonomous University of Barcelona. After working in diverse research projects both in academia and in industry, she is currently interested in re-shaping central carbon metabolism in Pseudomonas putida for White Biotechnology purposes.

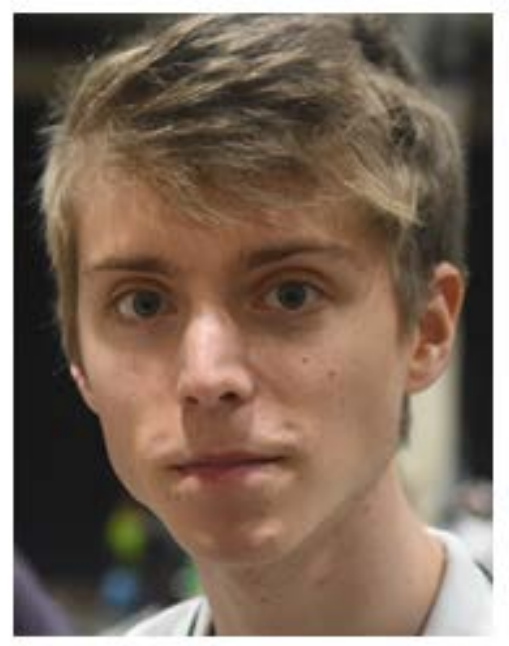

Antonin Cros received his B.Sc. degree in Health Biology and his M.S. degree in Fundamental Microbiology from the Paris-Sud University of Orsay. He joined the Systems Environmental Microbiology group at The Novo Nordisk Foundation Center for Biosustainability (Denmark) in 2018, first as a Master intern and then as a research assistant working in an industrial project. Following his general interest in harnessing the potential of microorganisms to solve global societal problems, he recently started his Ph.D. in the same group to develop synthetic pathways for the production of new-to-Nature halogenated compounds.

This article is protected by copyright. All rights reserved. 
Figures

Figure 1. Overview of evolutionary approaches to engineer bacterial cell factories. Genetic variation within a bacterial population can be exploited by taking advantage of spontaneous mutagenesis events or by artificially increasing mutation rates. The characteristics of the bacterial host, the type of phenotype to be improved, and the expected applications of the resulting strain define the approach to be used. Regardless of the methodology used to increase genetic variation within a bacterial population and/or to generate a combinatorial library of strains, efficient screening and selection methods are required to quickly fish the mutants displaying the (enhanced) phenotype of interest from the entire population. The bestperforming mutants can be used directly for production purposes or they can be further optimized in new cycles of improvement. Evolved populations and selected mutant strains with the desired phenotype can also be analyzed using wholegenome sequencing and Systems Biology tools, with the ultimate goal of identifying causal beneficial mutations that can be introduced into cleanbackground, naïve bacterial strains (i.e. reverse engineering). MCF, microbial cell factory.

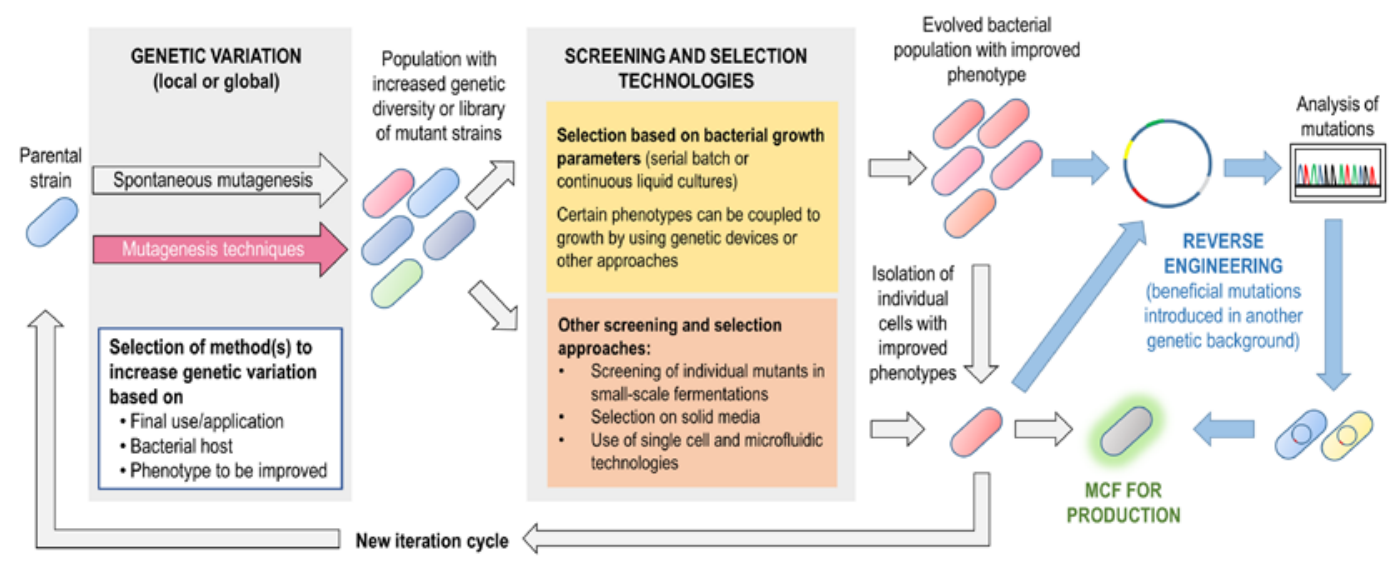

This article is protected by copyright. All rights reserved. 
Figure 2. Whole-genome approaches to increase genetic variation in bacteria. (A) Whole-genome, random DNA mutagenesis can be induced by treatment with a chemical or physical mutagen, or mediated by mutator alleles. (B) Construction of a library of shuffled strains through the recursive fusion of protoplasts from several parental strains, each of them displaying an advantageous phenotypic feature. (C) Creation of a library of transposon insertional mutants through the random integration of an antibiotic resistance gene in the target genome mediated by a transposase. (D) Construction of overexpression libraries using genomic DNA (gDNA, either from the bacterial host or from other organisms displaying phenotypic traits of interest), synthetic DNA, or metagenomic DNA samples. ORF, open reading frame. (E) Construction of a collection of mutants, which overexpress gene variants encoding transcriptional regulatory proteins (TRPs), displaying altered transcriptional responses that elicit the appearance of (often difficult-topredict) phenotypes of interest. (F) Isolation of spontaneous mutants resistant to ribosome-targeting drugs that have altered translational responses, leading to specialized phenotypes.

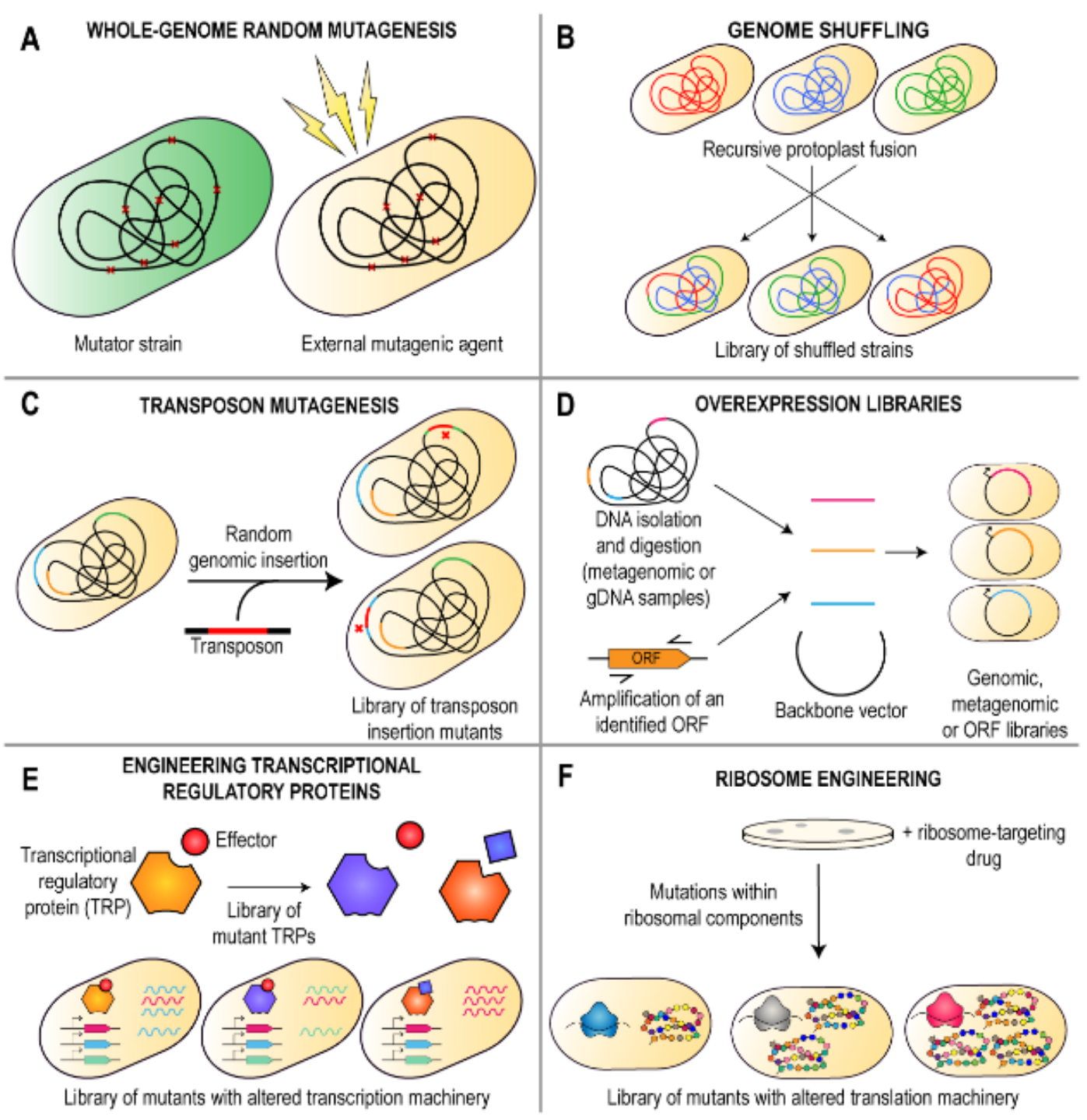

This article is protected by copyright. All rights reserved. 
Figure 3. Targeted DNA mutagenesis techniques to increase and exploit genetic variation in bacteria. (A) Construction of combinatorial libraries of mutant strains by in vivo homologous recombination techniques (i.e.

recombineering) using synthetic, linear DNA substrates equipped with homology arms. (B) The catalytically-inactivated Cas9 protein (dCas9) fused to a cytosine deaminase activity, together with a 20-nucleotide single-guide RNA (sgRNA), allows for the introduction of cytosine-to-thymine substitutions in a window located approximately 15-20 bases upstream of the PAM (protospacer adjacent motif) sequence. ${ }^{[81]}(\mathbf{C})$ The EvolvR device has been developed to diversify all nucleotides within a tunable window length. EvolvR consists of a CRISPR-guided Cas9 nickase (nCas9, which nicks the target locus) fused to a DNA polymerase (Poll3M) that mediates error-prone nick translation. ${ }^{[83]}$

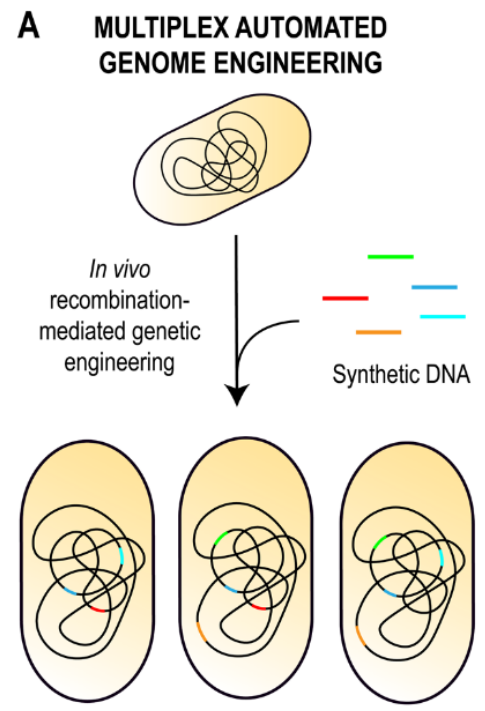

Combinatorial mutant library

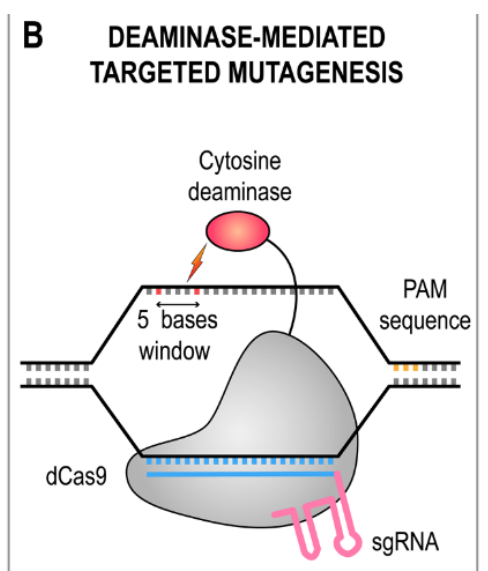

$-20-15$ $\begin{array}{ll}-20 & -15 \\ \text { CAACTGCGTAACAACAGCTTCGG } \\ \text { TAATTGCGTAACAACAGCTTCGG } \\ \text { TAACTGCGTAACAACAGCTTCGG }\end{array}$

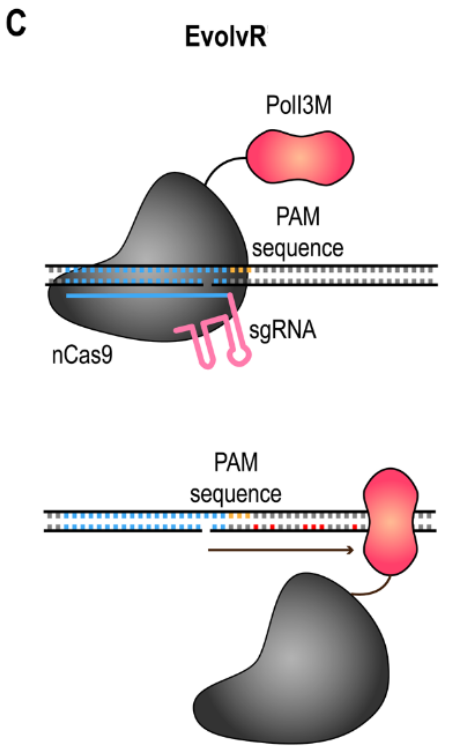

This article is protected by copyright. All rights reserved. 
Figure 4. Comparison of screening and selection technologies applied to exploit the genetic variation of bacterial populations or mutant libraries. Screening and selection technologies applied to exploit the (natural or induced) genetic variation of bacterial populations or libraries of mutant strains. Regardless of the methodology used to increase genetic variation, efficient screening and selection methods are required to quickly fish out mutants displaying the (enhanced) phenotype of interest. Different liquid culture setups (e.g. serial batch liquid cultivation, chemostat, or serial transfer in emulsion) can be used to enrich populations containing the best performing mutants if the phenotype can be coupled to growth parameters (e.g. growth rate, substrate affinity, or biomass yield). Selective, solid culture media or fluorescence-activated cell sorting (FACS) based-screening can be likewise applied to isolate individual mutants with enhanced performance for certain phenotypes. Additionally, small-scale fermentations of individual mutants, together with (high-throughput) analytical measurements, can be performed to isolate fitter cell factories for almost any phenotype.

Solid-media based
screening

This article is protected by copyright. All rights reserved. 
Figure 5. Growth-coupled production strategies to optimize the biosynthesis of a target product. A non-phosphorylative metabolism, coupled to the biosynthesis of the tricarboxylic acid (TCA)-cycle intermediate 2-ketoglutarate (2KG) from lignocellulosic sugars, was engineered in E. coli. ${ }^{[93 \mathrm{~b}]}$ This growth-based selection platform uses a $2 \mathrm{KG}$ auxotroph (the blockage of its synthesis within the TCA cycle is identified with a red cross), which allowed for the identification of several gene clusters mediating the assimilation of sugars via the non-native metabolic intermediate 2,5-dioxopentanoate. The application of this selection platform was demonstrated by engineering an artificial pathway for 1,4-butanediol production from D-xylose, L-arabinose, or D-galacturonate. Acetyl-CoA, acetyl-coenzyme A.

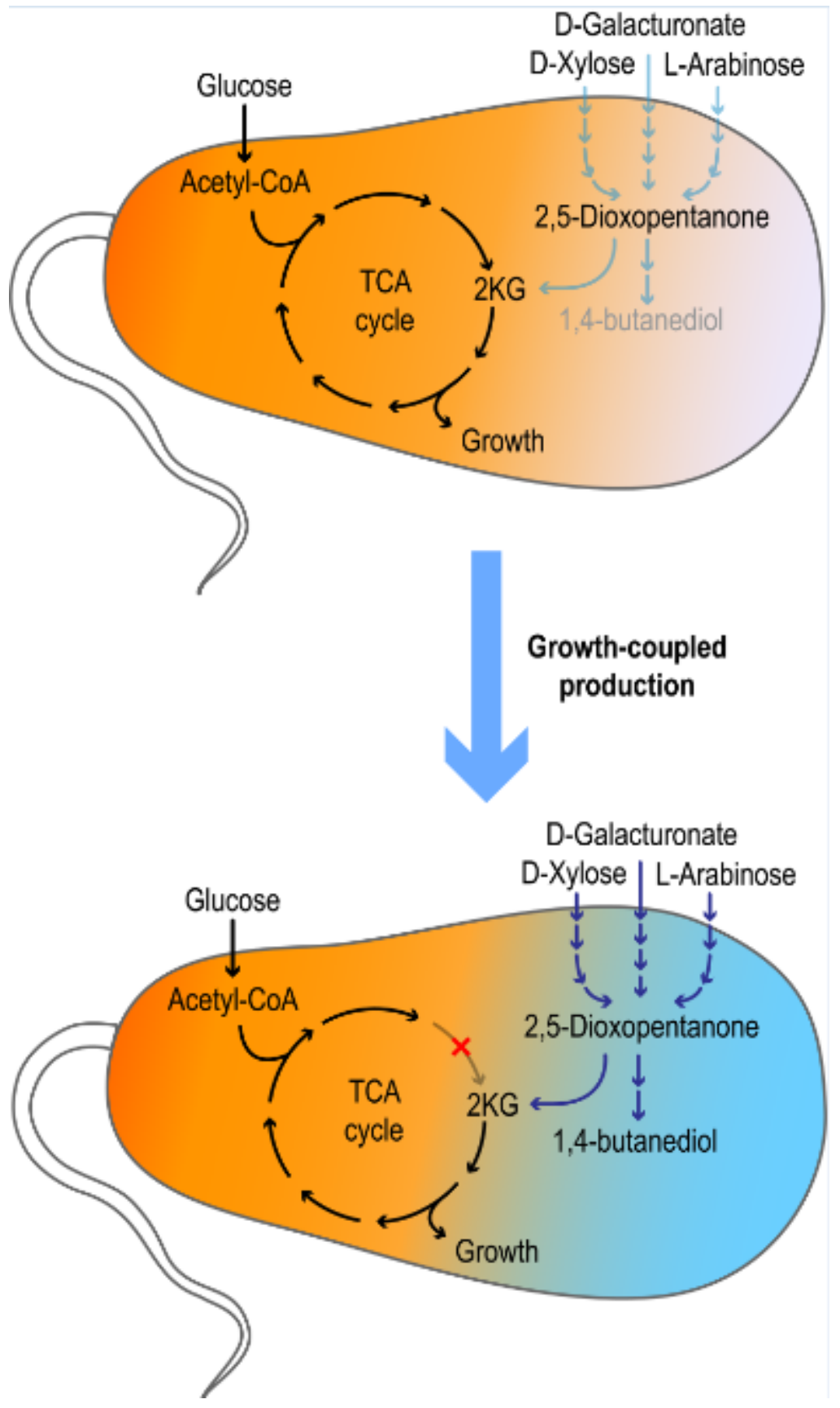

This article is protected by copyright. All rights reserved. 
Table 1. Selected examples of industrially-relevant phenotypes obtained by evolutionary approaches in bacterial cell factories.

\section{$\begin{array}{lll}\text { Phenotype } & \text { Description } & \text { Refence }\end{array}$}

Fast growth in Significant improvement (up to 1.6-fold) LaCroix et al. ${ }^{[23 b]}$

low-cost defined in the specific growth rate of $E$. coli

media MG1655 on minimal media with

glucose achieved by ALE.

Genetic stability Design of a genetically-stable E. coli Rugbjerg et al. ${ }^{[102]}$

strain for industrial production of

mevalonate. A product addiction-circuit,

engineered by controlling the expression

of two conditionally essential genes with

a mevalonate biosensor, enabled high-

yield production over 95 generations, at

which time the non-addicted strain

completely took over and abolished

production.

$\begin{array}{ll}\text { Efficient } & \text { B. subtilis mutants secreting up to 5-fold Naki et al. }{ }^{\left[{ }^{[9]}\right.} \\ \text { secretion } & \text { increased amounts of a protease isolated } \\ & \text { using a selection medium containing } \\ & \text { bovine serum albumin as the sole } \\ & \text { nitrogen source. The mutant population } \\ & \text { was progressively enriched during serial } \\ & \text { propagation in hollow fibers, in which }\end{array}$

This article is protected by copyright. All rights reserved. 
each colony grew in its own micro-

environment, and cross-feeding between

neighboring colonies was limited.

Limited Violacein biosynthesis was optimized in Jeschek et al. ${ }^{[103]}$

formation of by- $E$. coli by combinatorial pathway

products engineering. Due to the branched nature

of the biosynthesis pathway, the

occurrence by-products (e.g.

deoxyviolacein) is unavoidable. By

randomizing the expression level of the

pathway genes via RBS alteration,

mutant strains were selected that

displayed a 1.6- to 1.8-fold increase in

the violacein fraction.

$\begin{array}{ll}\text { High } & \text { Feedback-regulated evolution of Chou and } \\ \text { productivity } & \text { phenotypes was used to increase L- Keasling }{ }^{[41]} \\ & \text { tyrosine production in E. coli with the } \\ & \text { tyrosine-responsive transcriptional } \\ & \text { regulatory protein TyrR14 regulating } \\ & \text { expression of the dominant mutD5 } \\ & \text { mutator allele. Ten mutants had } \\ & \text { enhanced L-tyrosine production, and one } \\ & \text { exhibited a }>5 \text {-fold increase compared } \\ & \text { with the parental strain. }\end{array}$

Product
tolerance
the acid tolerance of a poorly-
characterized industrial strain of

This article is protected by copyright. All rights reserved. 
Lactobacillus. Shuffled strains grew at

substantially lower $\mathrm{pH}$ than the wildtype strain on both liquid and solid media. In addition, some shuffled strains produced 3-fold more lactic acid than the wild type at $\mathrm{pH}=4$.

$\begin{array}{ll}\text { Tolerance to } & \text { Saturation mutagenesis was combined } \\ \text { toxic compounds } & \text { with a growth-based selection program } \\ \text { found in raw } & \text { to isolate } E \text {. coli mutants with increased } \\ \text { materials } & \text { furfural tolerance from a library of } \\ & \text { mutants that overexpressed fucO } \\ & \text { variants (lactaldehyde oxidoreductase). }\end{array}$

${ }^{a} A L E$, adaptive laboratory evolution; $R B S$, ribosome binding site.

Table 2. Overview of the main techniques implemented to increase genetic variation in bacterial populations.

\begin{tabular}{lllcl}
\hline Technique & Description & Advantages & Disadvantage & $\begin{array}{c}\text { Main } \\
\text { applications }\end{array}$ \\
\hline Whole- & Increase of & - Technically & - Low & Improvement \\
genome & intrinsic & simple & frequency of & of simple \\
random & mutation rate & - Applicable & beneficial & phenotypes in \\
\hline
\end{tabular}

This article is protected by copyright. All rights reserved. 


\begin{tabular}{|c|c|c|c|c|}
\hline mutagenesis & $\begin{array}{l}\text { with mutagenic } \\
\text { agents } \\
\text { (physical/chemi } \\
\text { cal } \\
\text { mutagenesis) or } \\
\text { dominant } \\
\text { mutator alleles } \\
\text { (gene-encoded } \\
\text { mutagenesis), } \\
\text { followed by } \\
\text { screening and } \\
\text { selection }\end{array}$ & $\begin{array}{l}\text { to almost } \\
\text { any bacteria } \\
\text { - Non-GMOs } \\
\text { a } \\
\text { - Mutagenesi } \\
\text { s can be } \\
\text { coupled to } \\
\text { selection } \\
\text { - A priori } \\
\text { genome } \\
\text { knowledge } \\
\text { not needed }\end{array}$ & $\begin{array}{l}\text { mutations } \\
\text { - Accumulatio } \\
\text { n of } \\
\text { detrimental } \\
\text { mutations } \\
\text { - Narrow } \\
\text { mutational } \\
\text { spectra } \\
\text { - Dangerous } \\
\text { mutagens } \\
\text { needed } \\
\text { - Difficult to } \\
\text { identify } \\
\text { mutations } \\
\text { responsible } \\
\text { for observed } \\
\text { phenotypes }\end{array}$ & $\begin{array}{l}\text { non-well } \\
\text { characterized } \\
\text { bacteria }\end{array}$ \\
\hline $\begin{array}{l}\text { Construction } \\
\text { of whole- } \\
\text { genome } \\
\text { mutant } \\
\text { libraries }\end{array}$ & $\begin{array}{l}\text { Construction of } \\
\text { mutant libraries } \\
\text { (knock-out, } \\
\text { knock-down and } \\
\text { overexpression } \\
\text { libraries), } \\
\text { followed by } \\
\text { screening and } \\
\text { selection }\end{array}$ & $\begin{array}{l}\text { - Applicable } \\
\text { to many } \\
\text { bacteria } \\
\text { - Direct link } \\
\text { between } \\
\text { genotype } \\
\text { and } \\
\text { phenotype } \\
\text { - Reutilizatio } \\
\text { n of } \\
\text { libraries for } \\
\text { several } \\
\text { projects }\end{array}$ & $\begin{array}{l}\text { - Laborious } \\
\text { and time- } \\
\text { consuming } \\
\text { - Only } \\
\text { individual } \\
\text { contributions } \\
\text { of genes can } \\
\text { be identified } \\
\text { - Variation } \\
\text { followed by } \\
\text { selection }\end{array}$ & $\begin{array}{l}\text { Identification } \\
\text { of molecular } \\
\text { mechanisms } \\
\text { underlying } \\
\text { complex } \\
\text { phenotypes of } \\
\text { interest }\end{array}$ \\
\hline
\end{tabular}

This article is protected by copyright. All rights reserved. 


\begin{tabular}{|c|c|c|c|c|}
\hline $\begin{array}{l}\text { Genome } \\
\text { shuffling }\end{array}$ & $\begin{array}{l}\text { Libraries of } \\
\text { shuffled strains } \\
\text { via recursive } \\
\text { fusion of } \\
\text { protoplasts of } \\
\text { multiple } \\
\text { parental strains, } \\
\text { followed by } \\
\text { screening and } \\
\text { selection }\end{array}$ & $\begin{array}{l}\text { - Improveme } \\
\text { nt of } \\
\text { complex } \\
\text { phenotypes } \\
\text { - Non-GMOs } \\
\text { - High } \\
\text { genetic } \\
\text { variation } \\
\text { generated } \\
\text { - A priori } \\
\text { genome } \\
\text { knowledge } \\
\text { not needed }\end{array}$ & $\begin{array}{l}\text { - Variation } \\
\text { followed by } \\
\text { selection } \\
\text { - Low } \\
\text { efficiency in } \\
\text { Gram- } \\
\text { negative } \\
\text { bacteria } \\
\text { - Difficult to } \\
\text { identify } \\
\text { mutations } \\
\text { responsible } \\
\text { for observed } \\
\text { phenotypes }\end{array}$ & $\begin{array}{l}\text { Improvement } \\
\text { of complex } \\
\text { phenotypes in } \\
\text { non-well } \\
\text { characterized } \\
\text { Gram- } \\
\text { positive } \\
\text { bacteria }\end{array}$ \\
\hline $\begin{array}{l}\text { Engineering } \\
\text { transcription } \\
\text { al regulatory } \\
\text { proteins } \\
\text { (TRPs) }\end{array}$ & $\begin{array}{l}\text { Construction of } \\
\text { libraries of } \\
\text { endogenous, } \\
\text { exogenous, or } \\
\text { artificial TRPs } \\
\text { variants, } \\
\text { followed by } \\
\text { screening and } \\
\text { selection }\end{array}$ & $\begin{array}{l}\text { - Applicable } \\
\text { to many } \\
\text { bacteria } \\
\text { - Rapid } \\
\text { improveme } \\
\text { nt of } \\
\text { complex } \\
\text { phenotypes } \\
\text { - A priori } \\
\text { genome } \\
\text { knowledge } \\
\text { not needed }\end{array}$ & $\begin{array}{l}\text { - Variation } \\
\text { followed by } \\
\text { selection } \\
\text { - Laborious } \\
\text { and time- } \\
\text { consuming } \\
\text { - Only access } \\
\text { to latent } \\
\text { cellular } \\
\text { potential } \\
\text { - Genetic tools } \\
\text { and } \\
\text { protocols } \\
\text { required }\end{array}$ & $\begin{array}{l}\text { Optimization } \\
\text { of stress } \\
\text { tolerance } \\
\text { phenotypes }\end{array}$ \\
\hline $\begin{array}{l}\text { Ribosome } \\
\text { and RNA }\end{array}$ & $\begin{array}{l}\text { Isolation of } \\
\text { spontaneous }\end{array}$ & $\begin{array}{l}\text { - Technically } \\
\text { simple }\end{array}$ & $\begin{array}{l}\text { - Variation } \\
\text { followed by }\end{array}$ & $\begin{array}{l}\text { Overproducti } \\
\text { on of }\end{array}$ \\
\hline
\end{tabular}

This article is protected by copyright. All rights reserved. 


\begin{tabular}{|c|c|c|c|c|}
\hline $\begin{array}{l}\text { polymerase } \\
\text { engineering }\end{array}$ & $\begin{array}{l}\text { mutants with } \\
\text { drug-resistant } \\
\text { ribosomes and } \\
\text { RNA } \\
\text { polymerases, } \\
\text { followed by } \\
\text { screening and } \\
\text { selection }\end{array}$ & $\begin{array}{l}\text { - Applicable } \\
\text { to almost } \\
\text { any bacteria } \\
\text { - Non-GMOs } \\
\text { - A priori } \\
\text { genome } \\
\text { knowledge } \\
\text { not needed }\end{array}$ & $\begin{array}{l}\text { selection } \\
\text { - Low } \\
\text { frequency of } \\
\text { drug- } \\
\text { resistant } \\
\text { mutants } \\
\text { - Global } \\
\text { pleotropic } \\
\text { effects } \\
\text { - Only access } \\
\text { to latent } \\
\text { cellular } \\
\text { potential }\end{array}$ & $\begin{array}{l}\text { secondary } \\
\text { metabolites } \\
\text { and activation } \\
\text { of silent gene } \\
\text { clusters in } \\
\text { Actinobacteri } \\
\text { a }\end{array}$ \\
\hline $\begin{array}{l}\text { Combinatori } \\
\text { al pathway } \\
\text { engineering }\end{array}$ & $\begin{array}{l}\text { Construction of } \\
\text { combinatorial } \\
\text { libraries for the } \\
\text { optimization of } \\
\text { metabolic routes } \\
\text { (encoded in } \\
\text { plasmids or } \\
\text { genome), } \\
\text { followed by } \\
\text { screening and } \\
\text { selection }\end{array}$ & $\begin{array}{l}\text { - Optimizatio } \\
\text { n at } \\
\text { different } \\
\text { levels of } \\
\text { regulation } \\
\text { (e.g. } \\
\text { transcriptio } \\
\text { nal and } \\
\text { translational } \\
\text {, coding } \\
\text { sequences, } \\
\text { number of } \\
\text { gene } \\
\text { copies) }\end{array}$ & $\begin{array}{l}\text { - Variation } \\
\text { followed by } \\
\text { selection } \\
\text { - Off-target } \\
\text { mutations } \\
\text { (CRISPR } \\
\text { and } \\
\text { recombineeri } \\
\text { ng) } \\
\text { - Applicable } \\
\text { to a number } \\
\text { reduced of } \\
\text { bacterial } \\
\text { species }\end{array}$ & $\begin{array}{l}\text { Optimization } \\
\text { of } \\
\text { heterologous } \\
\text { biosynthetic } \\
\text { pathways }\end{array}$ \\
\hline $\begin{array}{l}\text { CRISPR- } \\
\text { guided local } \\
\text { random }\end{array}$ & $\begin{array}{l}\text { Creation of } \\
\text { locus-specific } \\
\text { random }\end{array}$ & $\begin{array}{l}\text { - Donor } \\
\text { DNA } \\
\text { template not }\end{array}$ & $\begin{array}{c}\text { - Off-target } \\
\text { mutations } \\
\text { - Applicable }\end{array}$ & $\begin{array}{l}\text { Phenotype } \\
\text { optimization } \\
\text { by coupling }\end{array}$ \\
\hline
\end{tabular}

This article is protected by copyright. All rights reserved. 


\begin{tabular}{lllll}
\hline mutagenesis & mutations via & used & to a reduced & random \\
& CRISPR-guided & (potentially & number of & mutagenesis \\
nuclease- & non-GMOs) & bacterial & of one or a \\
deficient Cas9 & - Mutagenesi & species & few genes \\
proteins fused to & s can be & & with selection \\
deaminases or & coupled to & \\
engineered & selection & \\
DNA & - High & \\
polymerases & mutation & \\
& rates & \\
& - Broad & \\
& mutational & \\
& spectra & \\
\hline
\end{tabular}

${ }^{a} G M O$, genetically-modified organism.

This article is protected by copyright. All rights reserved. 